\title{
Mapping Research on Sustainable Supply-Chain Management
}

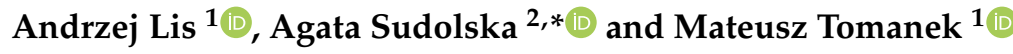 \\ 1 Department of Business Excellence, Faculty of Economic Sciences and Management, \\ Nicolaus Copernicus University, 87-100 Torun, Poland; andrzejlis@econ.umk.pl (A.L.); \\ mtomanek@umk.pl (M.T.) \\ 2 Department of Enterprise Management, Faculty of Economic Sciences and Management, \\ Nicolaus Copernicus University, 87-100 Torun, Poland \\ * Correspondence: aga@econ.umk.pl; Tel.: +48-56-6114890
}

Received: 1 April 2020; Accepted: 11 May 2020; Published: 13 May 2020

\begin{abstract}
The aim of the paper is to map the thematic landscape of the sustainable supply-chain management (SSCM) research field and contribute to exploring "relationships among specific constructs" in the field. The use of bibliometric methodology and the focus given to relationships among topics categorized into thematic clusters within the field are the features which differ the study from other reviews in the research field. The operational objectives of the study are as follows: (1) to profile the development of the SSCM research field and its scientific output, (2) to identify leading thematic areas in the field and explore their composition and relationships among them, (3) to identify 'hot', emerging topics in the field. The analysis of change in the number of publications and citations related to the SSCM concept supports the study of research productivity in the field. General publication profiling focuses on the identification of subject areas and leading contributors to the research field, i.e., countries, research institutions, source titles and authors. Keywords co-occurrence analysis is employed to identify and explore leading and emerging topics. The study points out that the main thematic areas in the SSCM research field are: (1) economy and management in the context of the environment, (2) supply chain in the context of sustainability, (3) sustainable supply chains-process approach, (4) decision making for SSCM, (5) the practice context of supply-chain management, and (6) competition and social responsibility (SR) issues. The most up-to-date topics of scientific inquiry in the field focus around the following issues: (1) human aspects, (2) sustainable supplier selection, (3) manufacturing, (4) circular economy, (5) efficiency, (6) sustainable practices, (7) commerce, (8) costs, (9) environmental impact, and (10) the textile industry.
\end{abstract}

Keywords: sustainable supply-chain management; bibliometrics; research profiling; science network mapping; keywords co-occurrence analysis; Scopus; VOSviewer

\section{Introduction}

A key challenge for modern companies is to strike a balance between achieving competitive advantage and acting sustainably while fulfilling their various stakeholders' expectations in order to preserve reputation, legitimation, and credibility [1]. For the last two decades, sustainability issues have been gaining prominence in several research areas. Among others, sustainability creates a major concern for organizations' practice of placing increased emphasis on the implementation of sustainability policies along their supply chains [1]. Organization's orientation towards sustainability means taking an attitude characterized by the anticipation of future consequences resulting from its decisions and activities. Such an organization perceives sustainability as a means to improve its financial results and strengthen competitiveness rather than a temporary trend or a fashion. Conceptually, sustainability 
refers to economic, social and environmental challenges and goals common to society as a whole and the planet [2]. Organizations focused on sustainability strive for maintaining a balance between meeting both coherent and conflicting interests of owners and other stakeholders, such as suppliers, business partners, customers, etc. [3]. Nowadays, supply-chain management has to go beyond pure economic issues. Instead it has to incorporate economic, social and environmental dimensions $[4,5]$. A supply chain includes all activities related to the flow of goods from the raw materials stage through production to end users, as well as information flows. The aim of supply-chain management is to fuse these activities to achieve organization's sustainable competitive advantages [6]. However, in recent research sustainable supply-chain management has become a significant issue. Sustainable supply-chain management integrates the concepts of supply-chain management and sustainability, and implies all activities of companies to enhance sustainability of their supply chains [7]. Sustainable supply-chain management is defined as the management of material, information and capital flows and cooperation among firms along a supply chain while taking into account goals from all three dimensions of sustainable development, i.e., economic, social, and environmental, which are driven by customer and stakeholder requirements [4]. Sustainability deficits along a supply chain may result in a decrease in firm's financial performance or a loss of its competitiveness [8]. Therefore, research on sustainable supply chains constitutes the field that has attracted high attention from both researchers and practitioners in recent years. This has led to an increasing amount of works in the field, covering a variety of subthemes such as: environmental management and performance, decision making following the triple bottom line approach, sustainable supplier evaluation and selection, sustainable supply-chain management risks, reverse logistics, supply-chain management for sustainable products, etc. [9-12].

The issues regarding various aspects of sustainable supply-chain management attract numerous scholars what results in the dynamic development of the research field. Scanning research productivity indexed within Scopus and Web of Sciences databases confirms the growing interest of academia in examining the issues related to the sustainable supply-chain concept and managing such supply chains. As of 27 December 2019, the search in titles, keywords and abstracts of Scopus-indexed publications, identified 1863 records for the phrase 'sustainable supply chain' (SSC), and 839 records for the phrase 'sustainable supply-chain management' (SSCM). The same query in the Web of Science Core Collection resulted respectively in 1182 (SSC) and 636 (SSCM) items. It is worth noticing that a significant part of this output has been amassed in recent years. Therefore, the role of mapping the science landscape within the research field becomes more and more important.

There are two methodological approaches to explore scientific outputs i.e.: (1) literature reviews $[13,14]$ including meta-analysis studies [15] and (2) bibliometric studies based on the research profiling method [16] and science network mapping methods [17]. Literature reviews are very often used in the SSCM research field. As of 19 April 2020, we identified 132 publications indexed in Scopus including the conjunction of phrases 'sustainable supply-chain management' and 'literature review' in their titles, keywords and abstracts. For the phrase 'sustainable supply chain', 223 publications were found. Among them, there are classical works published in the days of the SSCM concept emergence such as the studies by: Seuring and Müller [4], Carter and Rogers [18], or Carter and Easton [2]. However, new literature reviews are added as well to the body of knowledge, to mention among them the 'review of reviews' study by Carter and Washispack [19] or a few examples published very recently such as: Panigrahi, Bahinipati and Jain [20], Patel and Desai [21], Koberg and Longoni [22]. Although Carter and Washispack [19] claim that the SSCM research field has been saturated with systematic literature reviews (SLRs), and there is no need, with the exception of periodical updates, for new reviews, they identify two gaps related to: (1) exploring "relationships among specific constructs" and using reviews for "theory development", and improving "methodological rigor of future SSCM SLRs" [19] (pp. 242). Bibliometric methods, characterized by such rigor, seem to be a natural solution to support traditional literature reviews. In particular, science network mapping methods, e.g., co-word analysis [23], show potential to identify and explore the relationships among the concepts, approaches 
and constructs manifested through author keywords and keywords assigned to publications during indexation by databases.

Nevertheless, the growing SSCM research field has not been yet mapped with the use of the bibliometric methods. The search for the conjunction of phrases 'sustainable supply chain' and 'bibliometric' in the titles, keywords and abstracts of publications retrieves 11 records indexed in Scopus and six of them in Web of Science. After removing duplicates, there are found 13 publications meeting the searching criteria. However, while studied in a detailed way, none of them appears to map the research field of sustainable supply-chain management.

The first category among the retrieved publications provides bibliometric analysis of scientific output dealing with such issues as sustainable development [24], eco-innovation and circular economy [25], reverse logistics [26] or international logistics [27], which are related to the concept of sustainable supply-chain management. The second group of publications employs bibliometric methodology in order to profile and map the research fields of supply-chain management [28] and service supply-chain management [29], i.e., concepts much wider than sustainable supply chain management, which do not focus their attention on sustainable aspects of supply chains. Thirdly, among the retrieved items, there are two papers exploring the research field of green supply-chain management [30,31]. Although the concepts of green supply-chain management (GSCM) and sustainable supply-chain management (SSCM) share many similarities, the former is a narrower concept than the latter. This opinion is confirmed by the study by Ahi and Searcy [32] (pp. 329), who indicate that "definitions for GSCM [are] generally more narrowly focused than those for SSCM and [have] an emphasis on the characteristics of environmental, flow and coordination focuses. Although some definitions of SSCM show considerable overlap with definitions of GSCM, it is argued that SSCM is essentially an extension of GSCM". Finally, the other publications combining the interest in sustainable supply chains and employing a bibliometric approach focus their attention on sustainable supply chains in particular sectors e.g., dairy and fruits [33] or energy [34], in the context of a particular country, e.g., Brazil [35] or they analyze the field from the perspective of a given topic, e.g., digitalization [36] or decision support tools and performance management [37]. The aforementioned findings confirm that the research field of sustainable supply-chain management has not been mapped yet with the use of bibliometric methods, which opens a gap to support traditional literature reviews with rigorous co-word analysis.

The aim of the paper is to map the thematic landscape of the sustainable supply-chain management research field and contribute to exploring "relationships among specific constructs" in the field. The use of bibliometric methodology and the focus given to relationships among thematic clusters within the field and the items within the clusters are the features which differentiate our study from other reviews in the research field. The operational objectives of the study are as follows: (1) to profile the development of the SSCM research field and its scientific output, (2) to identify leading thematic areas in the field and explore their composition and relationships among them, (3) to identify 'hot', emerging topics in the field. The research process is guided through the following research questions: (1) how has research productivity evolved in the field?, (2) what are the subject areas and leading countries, research institutions, source titles, authors contributing to the amassing research output in the field?, (3) what are the leading topics attracting the attention of academia? (4) what are the emerging topics of interest in the research field? The aforementioned research questions and the findings from benchmarking of some other publications employing the keywords co-occurrence method to map research fields [38-40] determined the process of designing the study and influenced the structure of the paper. The remainder of the manuscript is structured as follows. First of all, the methodology of the study is presented, including research sampling, as well as research methods and instruments. Secondly, research productivity in the field and main contributors are analyzed. Thirdly, high-frequency keywords are clustered in order to identify and then explore the leading topics in the field. Fourthly, emerging research topics are recognized. Finally, the findings of the study are discussed. 


\section{Method of Study}

\subsection{Research Sample}

Scopus was used as the source of bibliometric data for research sampling. Launched in 2004, Scopus is considered to be a world-leading and dynamically developing bibliometric database [41]. Regardless of new entrants in the field of research databases, such as Dimensions [42], Scopus and Web of Science are the leading sources of bibliographic data. Being direct competitors, these two databases have been often compared and contrasted by the scientometrics community and found to be sources of quality bibliometric data, in spite of some limitations [43-47]. As of January 2020, Scopus covers 77.8 million records and over 25,100 titles issued by more than 5000 publishers [48]. Taking into account the number of publications, developed countries, e.g., the United States (Rank 1) and the United Kingdom (Rank 3) are the leading contributors. Nevertheless, an increasing role of some developing nations is worth noticing, especially China (Rank 2) and India (Rank 9). Of paramount importance for our study, the research by Zhu and Liu [44] shows an increasing interest of scholars in using Scopus, in line with Web of Science, for academic research, which may be a confirmation of its relevance for bibliometric analysis.

As of 27 December 2019, we searched for the phrase 'sustainable supply-chain management' in titles, keywords and abstracts (topic search) of the publications indexed in Scopus. There were no limitations in regard to a subject area or a time span of searched publications, in order to include all relevant works, provide a comprehensive picture of the research field and its multidimensionality, and illustrate its evolution over time. As a result of the sampling process, 839 bibliometric records (i.e., publications) were retrieved. Among them, articles and conference papers are the most numerous types of documents. The sample almost entirely consists of the publications written in English (99\%). All publications written in languages other than English constitute only 1\%. The detailed bibliometric description of the research sample is provided in Table 1.

Table 1. Parameters of the research sample.

\begin{tabular}{cc}
\hline Category & Items (N) \\
\hline Document type & Article (591); Conference Paper (113); Review (63); Book Chapter (50); Editorial (7); \\
Language & Conference Review (5); Erratum (1); Short Survey (1); Undefined (3) \\
& English (830); Chinese (3); Portuguese (3); German (1); Polish (1); Romanian (1); \\
Spanish (1)
\end{tabular}

Source: Own study based on data retrieved from the Scopus database (27 December 2019).

Moreover, in order to study the evolution of the research field, we extracted two sub-samples consisting of publications issued before and including $2010(\mathrm{~N}=57)$ and $2015(\mathrm{~N}=291)$.

\subsection{Research Methods and Instruments}

In our study, bibliometric methods are used to achieve the aim of the study. Literature reviews, which represent a traditional approach to analyze and synthesize research outputs, are considered to be biased and lacking rigor [13], and providing an incomplete picture due to a limited number of publications taken for qualitative analysis [16]. Therefore, more and more often bibliometric methods are recommended to supplement traditional literature reviews in exploration of research fields. Having revised the variety of definitions of bibliometrics, Broadus [49] (p. 376) characterizes it as "the quantitative study of physical published units, or of bibliographic units". As observed by Zupic and Čater [17] (p. 430) "[b]ibliometric methods employ a quantitative approach for the description, evaluation, and monitoring of published research. These methods have the potential to introduce a systematic, transparent, and reproducible review process and thus improve the quality of reviews". Scientific production in a research field may be explored through bibliometric studies based on the research profiling method [16] and science network mapping methods [17]. 
In our paper, the analysis of the change in the number of publications and citations related to the concept of sustainable supply-chain management supports the study of research productivity in the field. Moreover, some elements of the research profiling method [16] are included into the research toolbox. Research profiling, based on the number of indexed publications, points out the leading contributors in a research field, as well as subject areas and thematic areas within a field. This methodological approach is found to be used to explore research fields related to sustainable supply-chain management e.g., responsible and sustainable innovations [50]. Among the three main components of research profiling, i.e., general publication profiling, subject area profiling and topic profiling, cf. [51-53], we employ general publication profiling focused on the identification of subject areas and leading contributors to the research field, i.e., countries, research institutions, source titles and authors.

The methods of science network mapping include: citation analysis, co-citation analysis, bibliographic coupling, co-author analysis, and co-word analysis [17,54]. In our study, we employ keywords co-occurrence analysis (which is a kind of co-word analysis) to identify and explore leading and emerging topics. Co-word analysis is "a content analysis technique that uses patterns of co-occurrence of pairs of items (i.e., words or noun phrases) in a corpus of texts to identify the relationships between ideas within the subject areas presented in these texts. Indexes based on the co-occurrence frequency of items, such as an inclusion index and a proximity index, are used to measure the strength of relationships between items. Based on these indexes, items are clustered into groups and displayed in network maps" [55] (p. 134). This kind of methodology has been used among others to map the research fields related to the concept of sustainable supply-chain management focused on the issues such as: sustainability [40] or sustainable enterprises and sustainable organizations [56].

VOSviewer software $[57,58]$ is used to support clustering and visualizing the outcomes of high-frequency keywords co-occurrence analysis [59]. The publications comprising the sample provide 3599 keywords. Among them, 2630 are the keywords which occurred only once. Therefore, the number of high-frequency keywords to be selected for co-occurrence analysis, calculated in accordance with the formula provided by Donohue [60], cited by Guo et al. [40] (p. 7), is 72, which means the keywords with at least 13 occurrences should be taken into account. In the sample, there are 82 keywords meeting this threshold. Among them, we excluded 15 expressions referring to the research process such as: 'literature reviews' (with 27 occurrences), 'literature review' (36), 'article' (23), 'research' (20), 'surveys' (16), 'data envelopment analysis' (21), 'sensitivity analysis' (18), 'conceptual frameworks' (17), 'conceptual framework' (19), 'fuzzy sets' (16), 'systematic literature review' (20), 'interpretive structural modelling' (15), 'factor analysis' (13), 'case study' (17), 'content analysis' (13). In total 67 expressions were selected for co-occurrence analysis. The parameters of VOSviewer software used for analysis are provided in Table 2.

Bibliometric keywords co-occurrence analysis aimed at mapping leading research topics in the field is supported with core references/topic profiling [16,52], which is one of the sub-components of the research profiling method used in order to identify the most recognized publications in each of the thematic areas. These core references are then studied in accordance with the guidelines for systematic literature review [61]. 
Table 2. VOSviewer parameters used for analysis.

\begin{tabular}{|c|c|}
\hline Item & Characteristic/Value \\
\hline Type of analysis & Co-occurrence analysis \\
\hline Unit of analysis & All keywords \\
\hline Counting method & Full counting \\
\hline Layout & Association strength method \\
\hline Attraction & 2 (default setting) \\
\hline Repulsion & 0 (default setting) \\
\hline \multicolumn{2}{|l|}{ Clustering } \\
\hline Resolution parameter (detail of clustering) & 1 (default setting) \\
\hline Minimum cluster size $[\mathrm{N}]$ & 1 (default setting) \\
\hline Merging small clusters & Switched on \\
\hline \multicolumn{2}{|l|}{ Visualization } \\
\hline Scale & $\begin{array}{l}\text { item density visualization }-1.20 \\
\text { network and overlay visualizations-1.00 }\end{array}$ \\
\hline Weights & occurrences \\
\hline Labels size & 0.50 \\
\hline \multirow[t]{2}{*}{ Maximum number of lines } & 500 \\
\hline & main 2019 sample-67 \\
\hline \multirow[t]{3}{*}{ High frequency keywords used for analysis [N] } & 2015 sub-sample-49 \\
\hline & 2010 sub-sample-17 \\
\hline & main 2019 sample-13 \\
\hline \multirow[t]{2}{*}{ Minimum occurrences of a keyword used for analysis $[\mathrm{N}]$} & 2015 sub-sample-7 \\
\hline & 2010 sub-sample-3 \\
\hline
\end{tabular}

Source: Own study based on data retrieved from VOSviewer (27 December 2019).

\section{Research Productivity in the Field}

Czakon [61] claims that the dynamics of change in the number of publications may be a manifestation of a stage in the research field life cycle. Therefore, analyzing these trends contributes to better understanding of the field evolution. Among 839 publications included in the research sample, the earliest one dates back to 2001. Nevertheless, until 2007, only one or two publications were issued per year, which could have been recognized as weak signals of the upcoming interest of academia in researching the issues related to sustainable supply-chain management. Between 2008 and 2015, the number of publications per year increased from several to almost 70 . This period can be considered as the emergence phase of the research field. Then, in the second half of the 2010s, dynamic growth in research productivity has been observed as the number of publications increased from the level of around 100 in 2016 to 165 in 2019. Graphical illustration of the growing trend in the number of publications in the research field is presented in Figure 1. The dynamics of the increase in research productivity focused on sustainable supply-chain management is even more visible when the number of citations is taken into account (cf. Figure 2). Very limited in the 2000s, this measure increased by ten times between 2010 and 2015. In the second half of the 2010s, the growing trend has been maintained, and the measure attained almost 8000 citations in 2019. 


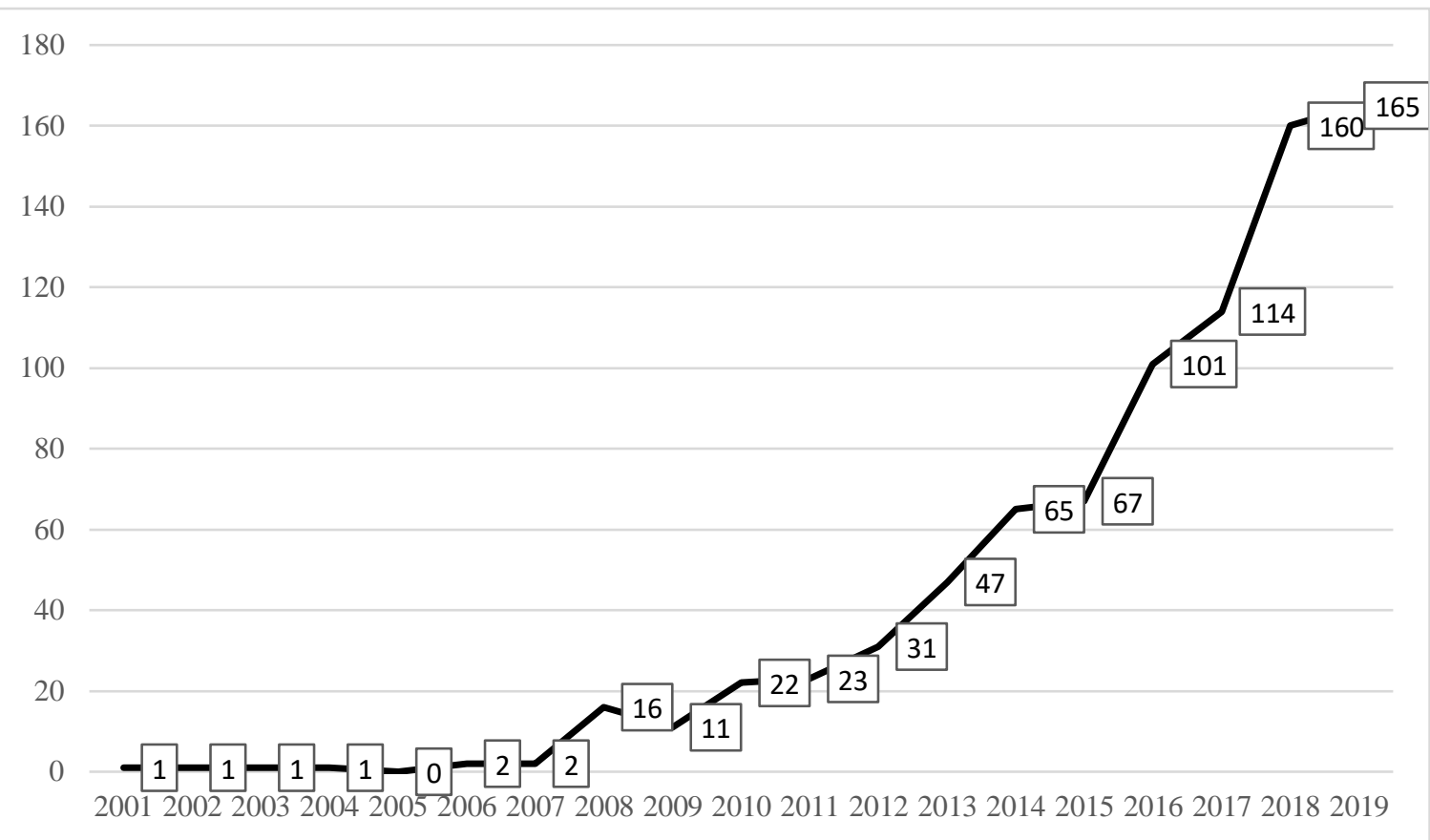

Figure 1. Scientific productivity of research on sustainable supply-chain management (SSCM) measured by the number of publications. Source: Own study based on data retrieved from the Scopus database (27 December 2019).

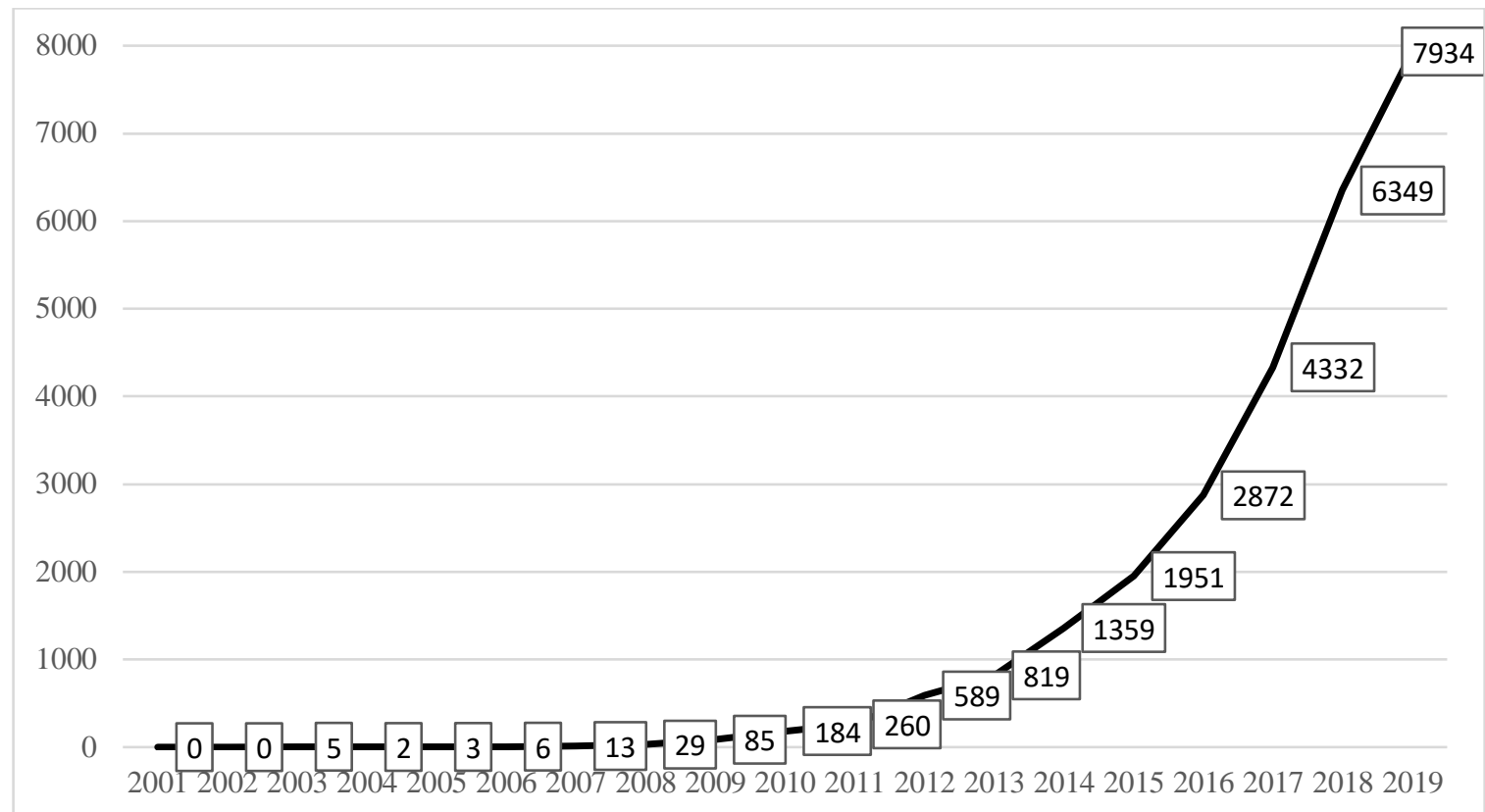

Figure 2. Scientific productivity of research on sustainable supply-chain management (SSCM) measured by the number of citations. Source: Own study based on data retrieved from the Scopus database (27 December 2019).

Research related to sustainable supply-chain management is distributed over 20 subject areas, categorized by Scopus. The majority of publications is indexed within the areas: Business, Management and Accounting (500 publications), Engineering (323) and Environmental Science (248). Among the top ten most productive nations, there are both developed and developing nations. The former are mainly represented by Anglo-Saxon countries (the United Kingdom, the United States, Australia, 
and Canada) and some continental European countries (Germany, Italy). The latter are Asian nations such as: China, India, Iran and Malaysia. Universität Kassel from Germany, which contributed with 38 publications, is found to be the most productive research institution in the field. Other highly productive universities are mainly the representatives of the countries identified as leading contributors in the field, e.g., the United Kingdom (two institutions), Iran (two), the United States (one), Canada (one). Moreover, Danish Syddansk Universitet and Dutch Delft University of Technology are among the top ten contributing institutions. Journal of Cleaner Production and Sustainability Switzerland are found to be leading source titles publishing research focused on the issues related to sustainable supply-chain management. Seuring from Universität Kassel, Germany, and Sarkis from Worcester Polytechnic Institute, United States, are worth mentioning as the most prolific authors in the field. The analysis of the number of publications written by the most productive authors shows that research in the leading universities is concentrated around a relatively small group of core scholars. The detailed data supporting general publication profiling of the sustainable supply-chain management research field are provided in Table 3.

Table 3. General publication profiling of the sustainable supply-chain management (SSCM) research field.

\begin{tabular}{cc}
\hline Category & Top Ten Items (Number of Publications) \\
\hline Subject area & Business, Management and Accounting (500); Engineering (323); \\
Environmental Science (248); Decision Sciences (186); Social Sciences (174); \\
Energy (171); Computer Science (155); Economics, Econometrics and Finance \\
(136); Mathematics (38); Arts and Humanities (18) \\
United Kingdom (118); United States (110); Germany (93); China (88); India (82); \\
Iran (55); Australia (45); Canada (40); Italy (37); Malaysia (35) \\
Universität Kassel, Germany (38); Islamic Azad University, Iran (15); Worcester \\
Polytechnic Institute, United States (14); Syddansk Universitet, Denmark (13); \\
Cardiff University, United Kingdom (11); University of Teheran, Iran (10); \\
University of Plymouth, United Kingdom (10); Delft University of Technology, \\
the Netherlands (9); Ryerson University, Canada (9) \\
Jesearch Institution \\
Chain Management (26); International Journal of Production Economies (24); \\
Resources Conservation and Recycling (20); Journal of Supply Chain \\
Management (19); International Journal of Production Research (17); Business \\
Strategy and the Environment (16); International Journal of Physical \\
Distribution and Logistics Management (16); International Journal of \\
Operations and Production Management (12) \\
Source Title \\
Seuring, S., Universität Kassel, Germany (32); Sarkis, J., Worcester Polytechnic \\
Institute, United States (17); Brandenburg, M., Universität Kassel, Germany (8); \\
Govidan, K., Syddansk Universitet, Denmark (8); Razaei, J., Delft University of \\
Technology, the Netherlands (8); Saen, R.F., Islamic Azad University, Iran (8); \\
Searcy, C., Ryerson University, Canada (8); Tseng, M.L., Asia University, Taiwan \\
(8); Walker, H., Cardiff University, United Kingdom (8); Beske, P., Leuphana \\
Universität Lüneburg, Germany (7) \\
\hline Author \\
\end{tabular}

Source: Own study based on data retrieved from the Scopus database (27 December 2019).

\section{Identifying Leading Research Topics}

\subsection{High-Frequency Keywords Clustering}

The study by Zhang and associates [62] confirms that author keywords and keywords added in the process of publications' indexation in databases are equally effective for bibliometric analysis aimed at exploring the structures of research fields. Therefore, we employed both categories of keywords for the co-occurrence analysis within the research field related to sustainable supply-chain management. In total, 839 publications included in the research sample provide 3599 keywords. Among them, those which occur the most often are: 'supply-chain management' (510), 'sustainable development' (349), 
'sustainable supply chains' (341), 'sustainable supply-chain management' (315), 'sustainability' (263), 'decision making' (101). The prominence of the aforementioned expressions is easier to observe with the item density visualization of high-frequency keywords in the sustainable supply-chain management research field (cf. Figure 3).

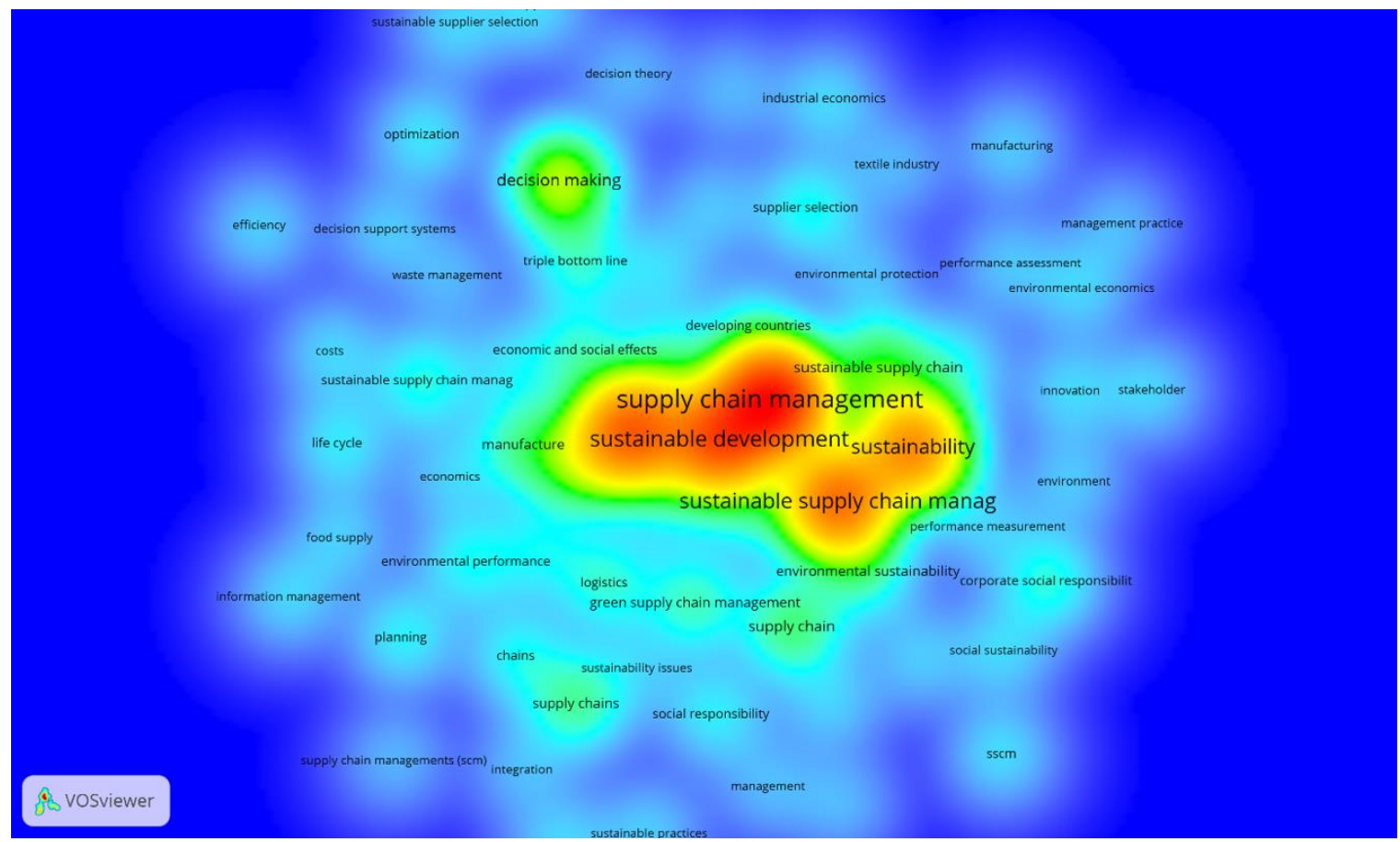

Figure 3. Item density visualization of high-frequency keywords in the sustainable supply-chain management (SSCM) research field. Source: Own study based on data retrieved from the Scopus database and analyzed with the use of the VOSviewer application (27 December 2019).

As already mentioned, the SSCM research field has been growing dynamically in the 2010s. In order to observe how much research interests have been changing over this decade, we identified the top ten high-frequency keywords in the research field at the beginning (2010), in the middle (2015) and the end (2019) of the period under analysis (cf. Table 4).

Table 4. The top 10 high-frequency keywords in the sustainable supply-chain management (SSCM) research field (ranked by the number of occurrences).

\begin{tabular}{|c|c|c|c|c|c|c|}
\hline \multirow{2}{*}{ Rank } & \multirow{2}{*}{$\begin{array}{r}2010 \\
\text { Keywords }\end{array}$} & \multicolumn{3}{|c|}{2015} & \multicolumn{2}{|l|}{2019} \\
\hline & & $\mathbf{N}$ & Keywords & $\mathbf{N}$ & Keywords & $\mathbf{N}$ \\
\hline 1. & supply-chain management & 31 & supply-chain management & 178 & supply-chain management & 510 \\
\hline 2. & sustainable development & 24 & sustainable development & 129 & sustainable development & 349 \\
\hline 3. & sustainability & 18 & sustainable supply chains & 122 & sustainable supply chains & 341 \\
\hline 4. & sustainable supply chains & 12 & sustainability & 95 & $\begin{array}{l}\text { sustainable supply-chain } \\
\text { management }\end{array}$ & 315 \\
\hline 5. & $\begin{array}{l}\text { sustainable supply-chain } \\
\text { management }\end{array}$ & 11 & $\begin{array}{l}\text { sustainable supply-chain } \\
\text { management }\end{array}$ & 91 & sustainability & 263 \\
\hline 6. & supply chains & 9 & $\begin{array}{c}\text { environmental } \\
\text { management }\end{array}$ & 36 & decision making & 101 \\
\hline 7. & $\begin{array}{l}\text { corporate social } \\
\text { responsibility }\end{array}$ & 6 & decision making & 27 & $\begin{array}{l}\text { environmental } \\
\text { management }\end{array}$ & 68 \\
\hline 8. & case studies & 5 & supply chains & 27 & sustainable supply chain & 64 \\
\hline 9. & $\begin{array}{l}\text { environmental } \\
\text { management }\end{array}$ & 5 & chains & 23 & supply chain & 52 \\
\hline 10. & logistics & 4 & supply chain & 18 & supply chains & 44 \\
\hline
\end{tabular}

Source: Own study based on data retrieved from the Scopus database and analyzed with the use of the VOSviewer application (27 December 2019). 
Taking into account the number of occurrences of the top ten high-frequency keywords, we observe stability of study interests in the process of the research field evolution. In all three samples, similar expressions manifesting leading research topics are found. In our opinion, two minor but interesting differences are worth noticing. In the 2010 sample, unlike in two other samples, the expressions 'corporate social responsibility' and 'logistics' are listed among the top 10 high-frequency keywords (Ranks 7 and 10 respectively). We assume that, in the early days of the research field, authors more often referenced to corporate social responsibility and logistics, which could be considered as the 'parent concepts', which SSCM derives from. For instance, as of 2019, both keywords 'corporate social responsibility' and 'logistics' achieved 33 occurrences which ranked them in positions 16-18 ex aequo. In regard to methodologies employed in exploring the SSCM field, as of 2010, case studies played a significant role, which is confirmed by including this expression among the top ten high-frequency keywords. Later on, although case study methodology was often used as well, its position was not so prominent. As of 2019, the keyword 'case study' is mentioned 17 times (Rank 59), and 'case studies' 13 times (Rank 76). Simultaneously, following the development of the field, 'literature reviews' (28 occurrences, Rank 23), and 'systematic literature reviews' (21 occurrences, Rank 41) have gained importance among research methodologies employed by scholars cultivating the field.

In order to identify the leading thematic areas within the research field, we conducted the network analysis. The outcome of this operation is the map of clusters including high-frequency keywords grouped into the categories showing relatedness and co-occurrence (cf. Figure 4). In the map, distance between the items is the measure of their relatedness (i.e. the closer the items are to each other, the more relatedness they show), while the strongest co-occurrences are marked with the lines between the items. The sizes of the frames correspond with the weights (prominences) of keywords measured by the number of occurrences.

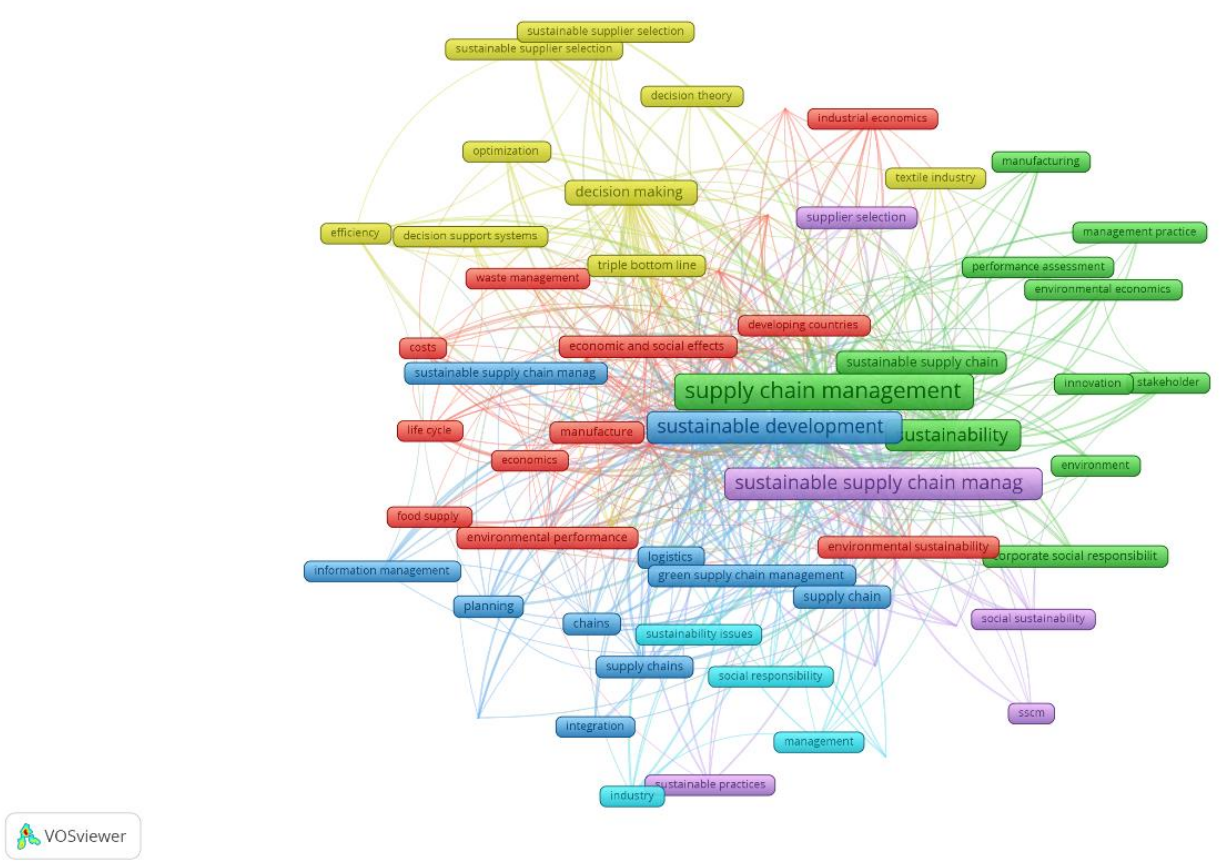

Figure 4. Clusters of high-frequency keywords in the sustainable supply-chain management (SSCM) research field. Source: Own study based on data retrieved from the Scopus database and analyzed with the use of the VOSviewer application (27 December 2019).

The network analysis of co-occurrence of high-frequency keywords related to research on sustainable supply-chain management indicates the six following thematic areas within the research field: (1) economy and management in the context of the environment, (2) supply chain in the context of sustainability, (3) sustainable supply chains-process approach, (4) decision making for SSCM, 
(5) practice context of supply chain management, (6) competition and social responsibility (SR) issues. The detailed composition of the clusters identified above is presented in Table 5 . The number of occurrences for high-frequency keywords included into the analysis ranges from 13 (in the case of ten items) to 510 ('supply chain management'). The minimum value of total link strength is 52 ('SSCM'), the maximum of 2324 ('supply chain management'). The most prominent keywords, i.e., those with the highest numbers of occurrences, links and total link strengths are shown in bold.

Table 5. Composition of high-frequency keywords clusters in the sustainable supply-chain management (SSCM) research field.

\begin{tabular}{|c|c|c|}
\hline $\begin{array}{c}\text { Cluster } \\
\text { Number/Label/Color }\end{array}$ & Items $(\mathbf{N})$ & Keywords (Occurrences; Links; Total Link Strength) \\
\hline $\begin{array}{l}\mathrm{C} 1 / \text { economy and } \\
\text { management in the } \\
\text { context of the } \\
\text { environment/red }\end{array}$ & 18 & 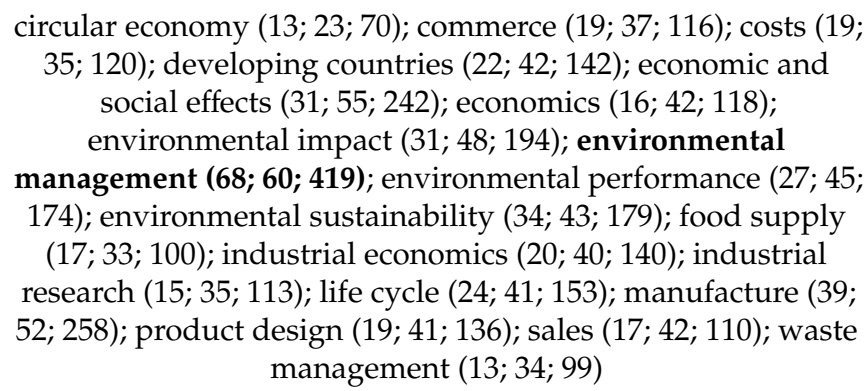 \\
\hline $\begin{array}{l}\text { C2/supply chain in the } \\
\text { context of } \\
\text { sustainability/green }\end{array}$ & 14 & $\begin{array}{l}\text { corporate social responsibility }(33 ; 35 ; 114) \text {; environment }(16 \text {; } \\
\text { 31; } 84) \text {; environmental economics }(18 ; 27 ; 87) \text {; environmental } \\
\text { protection }(14 ; 38 ; 85) \text {; human }(25 ; 46 ; 149) \text {; innovation }(19 ; 23 \text {; } \\
\text { 62); management practice }(13 ; 25 ; 72) ; \text { manufacturing }(17 ; 26 ; \\
\text { 79); performance assessment }(15 ; 27 ; 79) ; \text { performance } \\
\text { measurement }(16 ; 25 ; 57) ; \text { stakeholder }(19 ; 28 ; 96) \text {; supply } \\
\text { chain management (510; 66; 2324); sustainability (262; 66; } \\
\text { 960); sustainable supply chain }(\mathbf{6 4} ; \mathbf{5 3} ; \mathbf{2 7 2 )}\end{array}$ \\
\hline $\begin{array}{l}\text { C3/sustainable supply } \\
\text { chains-process } \\
\text { approach / blue }\end{array}$ & 12 & $\begin{array}{l}\text { chains }(27 ; 46 ; 179) \text {; green supply chain management }(38 ; 48 \text {; } \\
\text { 201); information management }(19 ; 35 ; 117) ; \text { integration }(13 ; 29 ; \\
\text { 72); logistics }(33 ; 44 ; 179) \text {; planning }(26 ; 40 ; 166) \text {; supply chain } \\
\text { (52; 47; 202); supply chain managements }(13 ; 28 ; 84) ; \text { supply } \\
\text { chains }(44 ; 53 ; 259) \text {; sustainable development }(349 ; 66 ; 1857) ; \\
\text { sustainable supply chain management (SSCM) }(32 ; 34 ; 124) ; \\
\quad \text { sustainable supply chains }(341 ; 66 ; 1837)\end{array}$ \\
\hline $\begin{array}{l}\text { C4/decision making for } \\
\text { SSCM/yellow }\end{array}$ & 10 & $\begin{array}{l}\text { decision making }(\mathbf{1 0 1} ; \mathbf{6 1} ; \mathbf{6 0 9 )} \text {; decision support systems }(16 ; \\
\text { 32; } 108) \text {; decision theory }(13 ; 26 ; 79) \text {; efficiency }(18 ; 24 ; 94) ; \\
\text { optimization }(23 ; 31 ; 122) \text {; social aspects }(23 ; 37 ; 156) ; \\
\text { sustainable supplier selection }(21 ; 27 ; 102) ; \text { sustainable } \\
\text { supplier selections }(19 ; 26 ; 110) \text {; textile industry }(13 ; 29 ; 71) ; \\
\text { triple bottom line }(31 ; 41 ; 145)\end{array}$ \\
\hline $\begin{array}{l}\text { C5/practice context of } \\
\text { supply chain } \\
\text { management /violet }\end{array}$ & 7 & $\begin{array}{l}\text { social sustainability }(19 ; 34 ; 101) \text {; SSCM }(21 ; 20 ; 52) \text {; supplier } \\
\text { selection }(30 ; 30 ; 127) \text {; sustainability performance }(16 ; 30 ; 88) \text {; } \\
\text { sustainability practices }(17 ; 35 ; 106) \text {; sustainable practices }(17 \text {; } \\
\text { 30; } 82) \text {; sustainable supply chain management }(\mathbf{3 1 5} ; \mathbf{6 5} ; \mathbf{1 0 6 0 )}\end{array}$ \\
\hline $\begin{array}{l}\text { C6/competition and SR } \\
\text { issues /light blue }\end{array}$ & 6 & $\begin{array}{l}\text { competition }(24 ; 46 ; 163) \text {; industry }(19 ; 35 ; 108) \text {; management } \\
(13 ; 30 ; 78) ; \text { resource based view }(13 ; 23 ; 56) \text {; social } \\
\text { responsibility }(25 ; 29 ; 86) \text {; sustainability issues }(13 ; 35 ; 81)\end{array}$ \\
\hline
\end{tabular}

Source: Own study based on data retrieved from the Scopus database and analyzed with the use of the VOSviewer application (27 December 2019).

Cluster 1 (marked in red in Figure 4) comprises 18 keywords. The location of the cluster extends mainly from the western part to the northern part of the map creating a total of 748 links with 2883 total link strength. The cluster is placed between Clusters 3 and 4, and fills also the space between Clusters 2 and 4 . The most important expressions that are the main nodes of this cluster are: 'environmental management', 'manufacture', 'environmental sustainability', 'economic and social 
effects', 'environmental impact', 'environmental performance', and 'developing countries'. This cluster is labeled as 'economy and management in the context of the environment'.

Cluster 2 (marked in green in Figure 4) comprises 14 keywords. The location of the cluster can be defined as north-eastern and eastern with a tendency to overlap the central part of the map. The central node is 'supply chain management' with 510 occurrences and 66 links whose total link strength is 2324 . The other main expressions that make up this cluster are 'sustainability' and 'sustainable supply chain'. Altogether this cluster creates 516 links, whose total link strength is 4520 . The keywords that make up this cluster are also major words defining this subject of research, hence the cluster is defined as 'supply chain in the context of sustainability'.

Cluster 3 (marked in blue in Figure 4) comprises 12 keywords. The location of the cluster can be described as southern and south-west, however the key nodes, i.e., 'sustainable development' and 'sustainable supply chains' are located in the central area of the map with a total of 690 occurrences, and the total link strength of these two nodes is 3694 . Other expressions that make up this cluster include: 'supply chain', 'supply chains', 'green supply chain management', and 'logistics'. This cluster together creates 536 connections, whose total link strength is 5277. The keywords that are grouped in this cluster focus on 'sustainable' and 'supply chains'. Hence, it is labeled as 'sustainable supply chains-process approach'.

Cluster 4 (marked in yellow in Figure 4) comprises ten keywords, creating 334 links with a total link strength of 1596. Although the nodes are not distributed close together, it can be said that the cluster mainly occupies the north-western part of the map, but its elements can be found also in the other parts of the map of the research field, which indicates a relatively weak strength of relationships between them. The dominating node of the cluster is 'decision-making', and other elements include: 'triple bottom line', 'optimization', 'social aspects', and 'sustainable supplier selection'. The keywords contained in this cluster designated the cluster as 'decision-making for SSCM'.

Cluster 5 (marked in violet in Figure 4) comprises seven keywords, creating 244 links with a total link strength of 1616. 'Sustainable supply chain management', located in the eastern part of the map center, is the most prominent expression in this cluster. An interesting phenomenon in this cluster is that the keywords such as 'sustainable supply chain management', 'supplier selection', 'social sustainability', and 'sustainable practices' are often connected with the nodes of the neighboring clusters, i.e., with Cluster 2 located in the northeast and Cluster 3 in the southern areas of the map. Cluster 5 has is branded as the 'practice context of supply chain management'.

Cluster 6 (marked in light blue in Figure 4) comprises five keywords. The keywords that make up this cluster have a smaller impact than the previous groups, since they have a total of 198 bonds with a total link strength of 572 . The name of this cluster ('competition and social responsibility issues') is derived from the following strongest keywords: 'social responsibility', 'competition', and 'sustainability issues'. This cluster is located primarily on the southern edges of the map, where distances from neighboring elements are far from each other, which may indicate a weak strength of relations between them.

Clustering shown in Figure 4 and Table 5 provides an overview of the SSCM research field structure. Based on the analysis of high-frequency keywords, it allows us to distinguish several subfields in the SSCM field. The visualization of clusters of high-frequency keywords in the field presented in Figure 4, combined with the analysis of core references in the distinguished clusters, confirms that there are many connections between the identified clusters (clusters are inter-connected), which suggests that they cover the dependent bodies of literature. The visualization presented in Figure 4 indicates several relations between keywords belonging to different clusters. For example, some connections between keywords from Cluster 2 (green) and Cluster 5 (violet) are observed. This is due to the fact that the keywords that make up both clusters relate to complementary issues. The keywords forming Cluster 2 refer to such issues as 'environmental protection', 'manufacturing', 'management practice', or 'corporate social responsibility'. The aforesaid expressions relate to the issues described by the keywords constituting Cluster 5, such as 'supplier selection', 'sustainable practices' or simply 
'sustainable supply chain management'. There are also several links between the keywords forming Cluster 1 (red) and Cluster 3 (blue). In this case, we notice some connections between such aspects as 'sustainable development', 'planning', 'green supply chain management' or 'integration' appearing as the keywords in Cluster 3 with the issues regarding 'manufacturing', 'environmental performance and impact', 'environmental management', 'circular economy', 'economic and social effects', 'costs' or 'developing countries'. Abovementioned relations reflect multidimensionality and complexity of the SSCM research field. On the other hand, the visualization presented in Figure 4 confirms that Cluster 4 (yellow) and Cluster 6 (light blue) cover relatively independent bodies of literature.

\subsection{Core References/Thematic Clusters Profiling}

Among the publications within the SSCM research field receiving the highest number of citations are the works by: Seuring and Müller [4], Carter and Rogers [18], Pagell and Wu [7], Carter and Easton [2], and Brandenburg, Govindan, Sarkis, and Seuring [63]. As pointed out in Table 2, Seuring from Universität Kassel, Germany, and Sarkis from Worcester Polytechnic Institute, United States, are the most prolific authors in the field. Profiling of core references within the thematic clusters is employed in order to explore the research status in the field. For each cluster, five the most cited publications had been selected, and then all remaining clusters were searched whether they included these items. The outcomes of the analysis are presented in Table 6 . While analyzing the presented data, co-sharing of many references by thematic clusters may be observed. This is particularly prominent in the case of Clusters 2 and 3.

Table 6. Core references in the clusters of high-frequency keywords in the sustainable supply-chain management (SSCM) research field (ranked by the number of citations).

\begin{tabular}{|c|c|c|c|c|c|c|c|}
\hline Reference & Citations (N) & $\mathrm{C} 1$ & $\mathrm{C} 2$ & $\mathrm{C} 3$ & $\mathrm{C} 4$ & C5 & C6 \\
\hline Seuring and Müller [4] & 2310 & - & 1 & 1 & 1 & - & 1 \\
\hline Carter and Rogers [18] & 1392 & - & 2 & - & - & - & 2 \\
\hline Pagell and $\mathrm{Wu}[7]$ & 697 & - & 3 & - & - & - & - \\
\hline Carter and Easton [2] & 627 & 1 & 4 & - & - & - & 3 \\
\hline $\begin{array}{l}\text { Brandenburg, Govindan, } \\
\text { Sarkis and Seuring [63] }\end{array}$ & 520 & 2 & 5 & 2 & 2 & - & - \\
\hline Hassini, Surti and Searcy [64] & 489 & 3 & 6 & 3 & - & - & - \\
\hline Seuring [5] & 488 & - & 7 & 4 & - & - & - \\
\hline Ahi and Searcy [32] & 465 & - & 8 & 5 & - & - & - \\
\hline $\begin{array}{c}\text { Govindan, Khodaverdi and } \\
\text { Jafarian [65] }\end{array}$ & 421 & 4 & 9 & 6 & 3 & 1 & - \\
\hline Gold, Seuring and Beske [66] & 391 & - & - & 7 & - & 2 & 4 \\
\hline $\mathrm{Wu}$ and Pagell [9] & 361 & 5 & 10 & 8 & 4 & - & - \\
\hline $\begin{array}{c}\text { Ashby, Leat and } \\
\text { Hudson-Smith [67] }\end{array}$ & 332 & 6 & 11 & 9 & - & 3 & - \\
\hline Tate, Ellram and Kirchoff [68] & 310 & - & 12 & 10 & - & 4 & - \\
\hline Pagell and Shevchenko [69] & 281 & - & 13 & - & - & 5 & - \\
\hline Büyüközkan and Çifçi [10] & 270 & - & 15 & 11 & 5 & 6 & - \\
\hline Beske, Land and Seuring [70] & 254 & 8 & 17 & 12 & - & 7 & 5 \\
\hline
\end{tabular}

Source: Own study based on data retrieved from the Scopus database (27 December 2019).

The core references in Cluster 1, labeled as 'economy and management in the context of the environment', are the works by Carter and Easton [2], Brandenburg, Govindan, Sarkis and Seuring [63], Hassini, Surti and Searcy [64], Govindan, Khodaverdi and Jafarian [65], and Wu and Pagell [9]. Carter and Easton [2] notice that the SSCM field evolved from the perspective of social and environmental research, then through the concept of corporate social responsibility, up to the "perspectives of sustainability as the triple bottom line and the emergence of SSCM as a theoretical framework" [2] (pp. 46). Brandenburg, Govindan, Sarkis and Seuring [63] describe the quantitative review of SSCM models for the purposes of identifying current gaps but also for determining future research perspectives 
based on the SSCM model. Similarly to Kannegiesser and Günther [71], the authors claim that SSCM model research can develop the inter-organizational perspective of supply chain management and extend it to the level of industry sectors. According to them, further SSCM research is also needed to integrate model-based methods with empirical research that focuses on ecological efficiency and environmental aspects. Hassini, Surti and Searcy [64] use a different approach to literature review in order to study two systems: one for managing sustainable supply chains and the other for developing performance measures for sustainable supply chains, finally presenting a case study illustrating the experience of a power company in determining performance indicators. Govindan, Khodaverdi and Jafarian [65] focus on management of food supply chains (FSCs), including the development of a sustainable SCM model for perishable food that takes into account the cost of carbon emissions. $\mathrm{Wu}$ and Pagell [9] analyze case studies in order to contribute to building theory and answering to the question: "how do organizations balance short-term profitability and long-term environmental sustainability when making supply chain decisions under conditions of uncertainty?" [9] (p. 577).

Cluster 2, labeled as the 'supply chain in the context of sustainability', includes the most cited core references in the whole research field. Suering and Müller [4] review 191 articles on sustainable supply chain management, published between 1994 and 2007. When creating the conceptual framework, the authors propose two separate strategies: (1) supplier management for risks and performance and (2) supply chain management for sustainable products. They also note that sustainable supply chain management is characterized by explicit integration of environmental or social objectives which extend the economic dimension to the triple-bottom-line (TBL). Hence, the article by Seuring and Müller is included in Clusters 2, 3, 4 and 5. The second most frequently cited article is the work by Carter and Rogers [18], which is categorized in Clusters 2 and 6. In their publication, the authors present the concept of sustainable development in regard to supply chain management. To achieve this, the authors study the concept of sustainable development focusing also on integration of economic, social and environmental criteria, the aim of which is to be able to achieve long-term economic viability. They also believe that vertical coordination is required to manage a supply chain as a whole. Pagell and Wu [7] notice that organizational ability to introduce innovation is the beginning of successful management of a sustainable supply chain, and that the precursor of sustainable supply chain management should have a managerial orientation. The list of top five core references in Cluster 2 is supplemented by the works of Carter and Easton [2] and Brandenburg and associates [63], already discussed in Cluster 1.

Cluster 3, labeled as 'sustainable supply chains-process approach', share the most cited core references with Clusters 1 and 2 [4,63,64]. For instance, Hassini, Surti and Searcy [64] refer to the serving system "or the development of performance measures for sustainable supply chains" [64] (pp. 69). Among other papers, Seuring [5] notes that over the past 15 years, during which over 300 articles on green or sustainable supply chains had been published, only 36 had applied quantitative models as research methodology. The environmental dimension clearly dominated in these studies, while social aspects were omitted or misinterpreted. Ahi and Searcy [32] also deal with green and sustainable supply chain management and analyze the definitions of GSCM and SSCM (which has a broader scope than GSCM).

'Decision-making for $\mathrm{SSCM}^{\prime}$ is a thematic area covered by publications categorized in Cluster 4. It shares the majority of its core references $[4,9,63,65]$ with the already studied clusters. Last but not least, Büyüközkan and Çifçi [10] analyze the problem of identifying an effective model based on sustainability principles for supplier selection operations in supply chains, noting that suppliers play a significant role at the beginning of a sustainable supply chain. Interestingly, the proposed solution for the assessment and selection of sustainable suppliers is further illustrated by the example of one of the largest producers of the Turkish household appliances industry.

Cluster 5, marked as the 'practice context of supply chain management', centers around the use of, among others, case studies, such as in the articles by Govindan, Khodaverdi and Jafarian [65], Büyüközkan and Çifçi [10] or by Beske, Land and Seuring [70]. Among other publications, Tate, Ellram and Kirchoff [68] analyze 100 selected CSR reports of enterprises in order to study supply chain 
management. They accomplish this by categorizing information into ten types of relationships with SCM: (1) 'supply chain', (2) 'institutional pressure', (3) 'community focus', (4) 'consumer orientation', (5) 'external environment ', (6) 'risk management', (7) 'measures', (8) 'energy', (9) 'healthcare', (10) 'green building'.

Cluster 6, labeled as 'competition and social responsibility issues', shares its leading core references $[2,4,18]$ with other clusters. Giving the particular emphasis to competition and social responsibility, Gold, Seuring and Beske [66] notice that valuable and rare resources and opportunities resulting from cooperation in the entire supply chain can become a source of sustainable competitive advantage for cooperating enterprises. This 'collaborative paradigm' in supply chain management treats strategic cooperation as a key source of competitive advantage built for the needs of the product's total life-cycle basis. Beske, Land and Seuring [70], in their research conducted in the food industry, find it is important to implement dynamic capabilities as an aspect that allows achieving competitive advantages when applying SSCM practices.

The relations between the distinguished clusters, mentioned in the previous section, have been confirmed by the analysis of core references assigned to the clusters, shown in Table 6 . The conducted analysis proves several links between Cluster 1, Cluster 2 and Cluster 3 . They share more than one third of core references mentioned in Table 6 with one another that refer to such issues as developing performance measures for SSCM or striving for obtaining balance between short-term profitability and long-term environmental sustainability. Additionally, the links between Cluster 2 and Cluster 5, observed in the visualization presented in Figure 4, have been proved by the analysis of core references shared by the distinguished clusters. Data in Table 6 indicate that there are more than one third of core references shared by Cluster 2 and Cluster 5 . They mainly refer to sustainable supplier selection, sustainable manufacturing practices, a process approach to SSC, environmental protection as well as measuring performance in accordance with the TBL concept.

\section{Identifying Emerging Research Topics}

The overlay visualization function of the VOSviewer application is employed in order to present emerging topics in the research field related to sustainable supply chain management. In the process of analysis, scores corresponding to the year of publications are assigned to the items, then the average year of publication is calculated and presented by VOSviewer. In the map (cf. Figure 5), the colors ranging from blue (the earliest publications) to yellow (the latest ones) may be used to find how the research interest in particular topics has been changing [58]. The following ten keywords in the sustainable supply chain management research field are found to have the most up-to-date average publication date: 'human' (2018.16)', 'sustainable supplier selection' (2017.32), 'manufacturing' (2017.29), 'circular economy' (2017.15), 'efficiency' (2017.06); 'sustainable practices' (2017.00), 'commerce' (2016.95), 'costs' (2016.95), 'environmental impact' (2016.94), 'textile industry' (2016.92). The obtained findings demonstrate a growing interest of researchers in the key aspects having influence on achieving sustainability while managing all activities related to the flow of goods from the raw materials stage through operations to the end user as well as the flow of information that constitute a supply chain. 


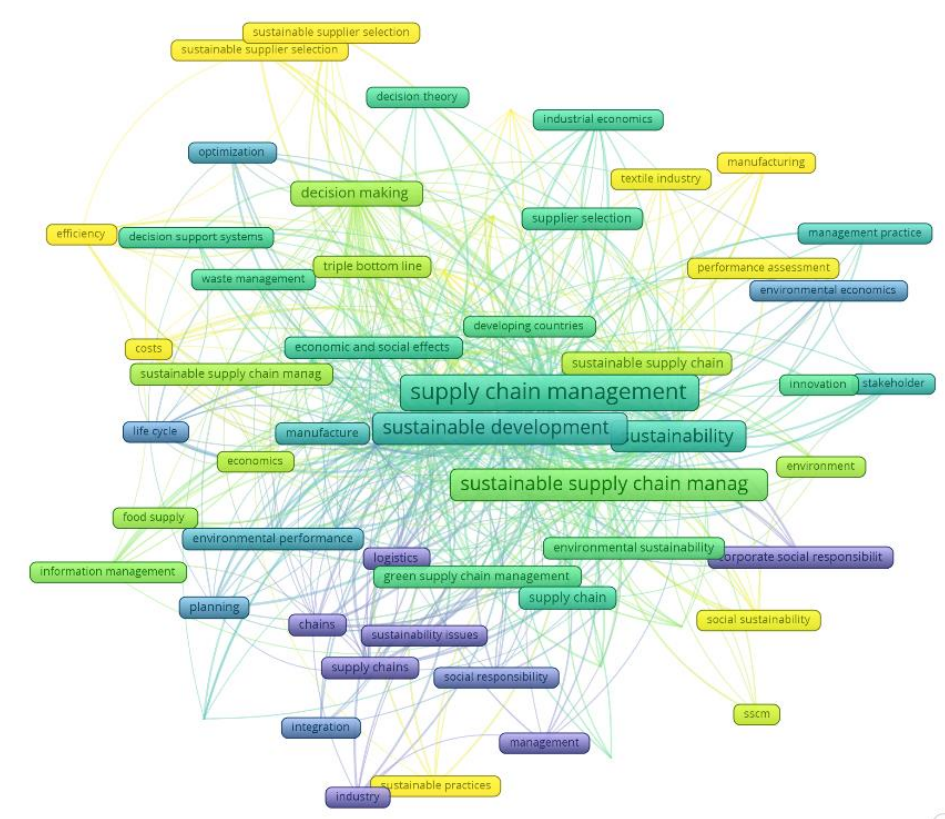

Figure 5. Overlay visualization of high-frequency keywords in the sustainable supply-chain management (SSCM) research field. Source: Own study based on data retrieved from the Scopus database and analyzed with the use of the VOSviewer application (27 December 2019).

Similarly to the analysis of leading thematic areas, we made an attempt to identify what topics were considered by scholars as 'hot' in various phases of the research field development. Due to a very limited number of publications comprising the 2010 sub-sample $(\mathrm{N}=57)$, we focused our attention on comparing and contrasting the status in the field as of 2015 and 2019. Table 7 presents the top high-frequency keywords in the research field, ranked by the average date of publication, in 2015 and 2019.

Table 7. The top high-frequency keywords in the sustainable supply-chain management (SSCM) research field (ranked by the average date of publication-ADP).

\begin{tabular}{ccccc}
\hline Rank & Keywords & NDP19 & ADP \\
\hline 1. & sustainability practices & 2014.43 & Keywords & 2018.16 \\
2. & chains & 2014.00 & sustainable supplier selection & 2017.32 \\
3. & global warming & 2014.00 & manufacturing & 2017.29 \\
4. & innovation & 2014.00 & circular economy & 2017.15 \\
5. & sustainable supply chain management & 2014.00 & efficiency & 2017.06 \\
6. & environmental impact & 2013.86 & sustainable practices & 2017.00 \\
7. & performance measurement & 2013.86 & commerce & 2016.95 \\
8. & environmental sustainability & 2013.77 & costs & 2016.95 \\
9. & product design & 2013.75 & environmental impact & 2016.94 \\
10. & environmental performance & 2013.57 & textile industry & 2016.92 \\
\hline
\end{tabular}

Source: Own study based on data retrieved from the Scopus database and analyzed with the use of the VOSviewer application (27 December 2019).

Considering the top ten latest high-frequency keywords in the SSCM field, we observe a significant change in topics that can be considered as new and 'hot' in the given periods. In both analyzed samples, some similar expressions displaying new research topics are found, e.g., 'sustainable practices' or 'environmental impact'. However, based on the data presented in Table 7 the evolution of researchers' interests in the area of SSCM field is visible. Topics related to such keyword as 'performance measurement', 'chains' or 'sustainable supply chain management' listed in 2015 have 
evolved into issues referring to such keywords as 'efficiency', 'sustainable supplier selection' or 'manufacturing'. What seems interesting is that in 2015 authors concentrating on SSCM more often referenced 'innovations' and 'product design' in their studies. Instead of these issues, four years later, the topics focused on 'circular economy' appeared, which in fact covers the issues related to 'efficiency', 'innovation', 'product design', 'performance measurement', 'commerce', etc. As circular economy refers to an economic system aimed at eliminating waste and the continual use of resources, it requires keeping products, equipment and infrastructure in use for longer through improving the resources productivity. Therefore, we assume that the keyword 'circular economy', which appeared among the top ten up-to-date high-frequency keywords in the SSCM research field in 2019, is an 'umbrella' covering a number of some smaller topics in the studied area. Another interesting observation is the fact that in the 2015 sample, unlike in the other one, the expression 'global warming' is listed among the top ten up-to-date high-frequency keywords. We suspect that the issue of global warming has in time become one of the elements of the research area concerning the broadly understood impact of business on the natural environment which is associated with the keyword 'environmental impact'. On the other hand, in the 2019 sample the phrases 'human' as well as the 'textile industry' appear among the top ten up-to-date high-frequency keywords. The expression 'human' refers to several social issues related to SSCM. In turn, the appearance of the emerging topic labeled as the 'textile industry' results from the fact that in the contemporary economy, textile supply chains are becoming increasingly global. Therefore, the rising level of outsourcing to developing countries has placed an increasing focus on sustainability. In consequence, the need to understand how to integrate sustainability into globally fragmented supply chains is highly important and thus this area attracts many researchers in the field.

\section{Discussion}

The analysis of literature on sustainable supply chain management allows us to identify and explore the leading thematic areas in the field, which include: (1) economy and management in the context of the environment, (2) supply chain in the context of sustainability, (3) sustainable supply chains-process approach, (4) decision making for SSCM, (5) the practice context of supply chain management, and (6) competition and social responsibility (SR) issues. Mapping of the scientific landscape in the research field is supported with the identification of emerging topics. The most up-to-date topics of scientific inquiry in the field focus around the following issues: (1) human aspects, (2) sustainable supplier selection, (3) manufacturing, (4) circular economy, (5) efficiency, (6) sustainable practices, (7) commerce, (8) costs, (9) environmental impact, and (10) the textile industry.

Nowadays, considerable attention of the researchers interested in SSCM is placed on building sustainable supply chains by combining economic, social and environmental dimensions in accordance with the triple bottom line concept (TBL) referring to the balance between the economy, the society and the natural environment. According to the TBL concept, business entities should focus on three different so-called bottom lines. The first bottom line refers to the traditional economic (financial) dimension of a company, which is called 'Profit'. The second bottom line is called 'People' and it regards the degree of social responsibility in all their activities. Finally, the third bottom line is labeled as 'Planet' and refers to the degree of business's environmental responsibility. TBL idea strives to ensure that the company's social and environmental activities are taken into account in the same way as its financial results [72]. Today, there is considerable agreement among scholars and practitioners on the view that if a company aspires to achieve a particular level of sustainability, it has to make much efforts to incorporate three components of the TBL concept along its whole supply chain $[2,4,18,29,32,70,73-75]$. Moreover, the economic, social, environmental dimensions of the triple bottom line approach are complementary and connected to each other, having some common drivers, enablers, and barriers within a supply chain $[64,76]$. Taking the above into consideration, it is impossible to separate economic issues from social or environmental ones.

The knowledge domain of sustainable supply chain management is developing fast. In academia, more and more attention is paid to discussing sustainable supply chain management by building on 
the TBL approach, integrating economic, social, and environmental dimensions into supply chains. It is worth noticing that these fundamental aspects are still very appreciated by the scholars cultivating in the field. Emerging topics identified in our study (e.g., 'manufacturing', 'supplier selection', 'efficiency', 'costs', 'human' aspects, 'sustainable practices', 'environmental impact', and 'circular economy') directly invoke to the TBL concept dimensions proposed by Elkington [72]. All aforementioned aspects are interrelated. Effective sustainable supply chain management requires a particular strategy towards supplier assessment and selection, manufacturing technologies and practices that mitigate influence on the natural environment. Nowadays, researchers spend much effort on explaining the relationships between sourcing and supplier selection, optimization of several business areas, such as manufacturing or transport, etc. and environmental impacts of business. Incorporating all these aspects into sustainable supply chain management is perceived as fundamental not only for resource saving and eliminating waste, but also for improving productivity [31,77].

We assume that the increasing researchers' interest in the ways of incorporating the TBL idea into companies' strategies and operations implies the leading topics in the field of SSCM referring to 'economy and management in the context of the environment' and 'supply chain in the context of sustainability'. Furthermore, while discussing the leading topics in the field of sustainable supply-chain management, an important issue refers to the process approach to managing sustainable supply chains $[64,70]$. Since recent growing pressure from several groups of stakeholders has prompted the manufacturing industry to integrate sustainability-conscious practices into their entire supply chains, the companies need to shift from optimization at the firm level to the entire supply chain. Then the aforesaid issues reflect the economic aspects associated with the TBL concept. However, a shift from optimization at the firm level to the entire supply chain is very complex. A supply chain involves management of product flows from the initial sources of raw material to the end-user customers in both forward and reverse directions, thus incorporating sustainability into supply chain requires a process approach $[64,78]$.

The process approach to sustainable supply chain management refers to the aspects regarding decision making. This area is another leading topic identified in the conducted study. Decision making for sustainable supply chain management is closely related to supplier selection and assessment, found among emerging topics. Supplier selection attracts particularly the interest of Büyüközkan and Çifçi [10]. The aforesaid authors identify and discuss an effective model based on sustainability principles for supplier selection operations in supply chains. While describing their framework, they highlight the importance of suppliers who constitute the first element of a sustainable supply chain. Similarly, Reefke, Ahmed and Sundaram [11] highlight that supply chains are complex systems, and decision making and support processes for the development and management of such multifaceted entities are quite challenging. They underlie the fact that that current supply chain practices are often ad hoc and lack end-to-end support for the gradual transformation towards supply chain sustainability. Given this, the aforementioned authors propose a model for sustainable business transformation. Moreover, while considering decision-making issues, it should be noted that sustainable supply-chain management, due to its inherent complexity, requires continuous analysis of the internal and external situation of a company. Moreover, it is always loaded with particular risks resulting from the choice of strategy and resource allocation. Hence, while considering decision-making processes, supply chain management should be supported by a variety of instruments to streamline organizational structures and processes [12].

The issue of decision making for creating sustainable supply chains is also the focus of $\mathrm{Wu}$ and Pagell [9]. These researchers address the problem referring to obtaining balance between short-term profitability and long-term environmental sustainability under conditions of uncertainty. The aforesaid aspect is directly associated with one of the identified leading topics focused on the practical context of supply chain management. The practical context of supply chain management refers to the issues related to supplier selection, sourcing, environmental-oriented technological processes implementation, sustainability performance, etc. $[31,77,79]$. Focusing on these issues leads to the aspects regarding 
SSCM through the lens of business impact on the natural environment which is one of the TBL concept components [9]. Nowadays, there is a considerable agreement among researchers and practitioners on the fact that environmental changes are upon us. Environment pollution and depletion of resources have been troubling both human common life as well as business over the last two decades. Therefore, all strategies and practices aimed at preventing environmental degradation become a point of interest for the researchers from different disciplines [31].

Social responsibility and human aspects constitute another leading thematic area in the field. As argued by Zorzini et al. [76], a company aimed at successful managing its supply chain in line with sustainability priorities has to focus not only on profits and its impact on the natural environment, but also on the social well-being of employees and a wider community what is the third pillar of the TBL concept. Despite the fact that importance of being aware of social practices amongst supply chain partners and business environmental impacts are hard to dispute, there are many intrinsic challenges to incorporating social and environmental concerns into decisions regarding supply chain management in practice. Therefore, it is not surprising that, as a challenging issue for many business entities and their suppliers, the practical aspects of sustainable supply chain management constitute an area of researchers' interest.

Building the company's sustainable supply chain on the TBL idea draws researchers' attention to the aspects of employees' well-being as well as social benefits related to SSCM. We assume that this trend of academia's interest results in the fact that among the most visible emerging topics one can find the issues related to widely understood social issues (which in our study is manifested by one of the emerging topics labeled 'human') encompassing such aspects as compliance with human rights, discrimination, child labor, long working hours, occupational health and safety, forced compulsory labor, security practices, freedom of employees' association and collective bargaining, unfair competition, etc. Therefore, sustainability aspects, considered through the lens of above mentioned problems, are sometimes perceived as constituting a new idea of humanity. It is worth noting that the research stream corresponding with human aspects of sustainable supply chain management and gaining an increasing interest in academia is socially responsible sourcing, that focuses on the upstream management of the supply chain [76].

The last emerging topic identified in this study has been labeled as the 'textile industry'. This phenomenon seems to result from the fact that nowadays companies operating in the textile sector are increasingly under the spotlight for their involvement in social and environmental issues. As noted by several authors, the issue of sustainable supply chain management in the textile industry becomes increasingly important $[1,12,73]$. This is caused by the fact that companies operating in the textile industry are strongly exposed to the occurrence of social and environmental problems, both in the production phase and the entire supply chain [12]. As far as the social dimension of TBL idea is concerned, it needs to be highlighted that the aspects related to sustainable supply chain management and the textile sector refer to such issues as labor intensiveness and its outsourcing activities to developing countries with usually high corruption rates. Thus, transparency of suppliers, social risks related to child labor or extensive work hours and the environmental impacts, following global initiatives like Global Compact or international standards and principles, such as AA1000, EMAS, ISO 14000, ISO 19011, etc., are vital areas of interest for the researchers analyzing the textile sector. While considering the impact of the textile industry on the environment, it is of great significance to note that environmental issues arise at all stages of the textile supply chain. As highlighted by Oelze [1] as well as Zimon and Domingues [12], the expansion of textile production and consumption resulted in increasing pollution, water shortages, fossil fuel and raw material depletion, and climate change. In addition, the problems regarding achieving sustainable supply chain management in the textile industry involve strong dispersion of individual links in the supply chain resulting from the efforts to minimize labor and production costs, widespread use of outsourcing of finished products far away from sales markets or problems with managing the return of post-seasonal clothes [12]. 
Our findings related to the leading thematic areas and emerging topics in the field of sustainable supply chain management are aligned with the evidence found in the relevant literature. The issues regarding incorporating economic, social and environmental dimensions of business activities in line with the TBL approach are discussed by many researchers in the field $[4,5,18,70,75]$. Among the publications focusing on social aspects in relation to sustainable supply chain management it is worth pointing out the works of Walker and Jones [80], Zorzini, Hendry, Huq, and Stevenson [76], Freise and Seuring [81], Köksal, Strähle, Müller and Freise [73]. The studies of Zorzini et al. [76] as well as Köksal et al. [73] present findings of two extended literature reviews on the social dimension of sustainable supply chain management. Additionally, the issues considering the environmental impact in relation to sustainable supply chain management are discussed by many authors in the field. For instance, Ahi and Searcy [32] or Shan and Wang [31] emphasize integrating environmental considerations into supply chain management research and practice. Finally, the findings regarding the identified emerging topic that was labeled as the 'textile industry' are consistent with the literature review, too. As noticed by Oelze [1], sustainability constitutes a major concern for textile companies' practice of placing increased emphasis on the implementation of sustainability policies along their supply chains. This phenomenon implies several problems to be studied both by the researchers and practitioners, such as transparency of suppliers influencing supplier assessment and selection, social risks resulting from child labor problems, work conditions, extensive work hours or environmental impacts. This results in the increasing interest of academics in the field, e.g., the works regarding sustainability in the textile sector, apart from Oelze [1], are provided by Freise and Seuring [81], Zorzini et al. [76], Giannakis and Papadopoulos [82], Köksal et al. [73] or Sudolska, Drabkowska-Skarba, Łapińska, Kązzielawski and Dziuba [83]. The aforementioned authors examine several aspects related to integrating the triple bottom line approach along the supply chain in the textile sector. However, all of them highlight the growing focus of the sector on developing sustainable supply chain management models. Thus, we assume that this will be really a fast developing topic within the studied field.

\section{Conclusions}

Summing up, the conducted literature analysis allows us to answer the research questions that have been addressed. The study has: (1) discovered the trends in research productivity in the field, (2) identified the main subject areas and leading contributors (countries, research institutions, source titles, authors) to the amassing research output in the field, (3) identified the leading and emerging topics of scientific inquiry (4) discussed the research status in the field.

Addressing the first research question we referred to the evolution of research productivity in the SSCM field. Investigation of research productivity indicates three phases in the development of the SSCM research field. Firstly, in 2001-7, weak signals of the upcoming interest of academia were noticed. The period 2008-15 can be considered as the emergence phase. Since 2016, the growth phase of the research field life cycle has been observed, which has resulted in amassing the scientific output. The second research question posed in the paper was aimed at identifying subject areas and leading countries, research institutions, source titles, and authors contributing to the amassing research output in the field. Answering this question, we have found out that the publications related to SSCM refer to over 20 subject areas; however, most of the works are indexed in the areas of Business, Management and Accounting, Engineering as well as Environmental Science. Among the most productive nations in the research field, there are both developed (Anglo-Saxon and European continental) countries as well developing nations (mainly from Asia). Universität Kassel from Germany is found to be the most productive research institution in the field, with Journal of Cleaner Production and Sustainability Switzerland being the leading source titles. Raising the third research question we consulted an issue of the leading topics attracting the attention of researchers in the field. Based on the conducted study we recognize that the main topic areas in the SSCM research field are: (1) economy and management in the context of the environment, (2) supply chain in the context of sustainability, (3) sustainable supply chains-process approach, (4) decision making for SSCM, (5) the practice context of supply chain 
management, and (6) competition and social responsibility (SR) issues. Finally, answering the fourth research question, we found out that the most up-to-date topics of scientific inquiry in the field focus around the following issues: (1) human aspects, (2) sustainable supplier selection, (3) manufacturing, (4) circular economy, (5) efficiency, (6) sustainable practices, (7) commerce, (8) costs, (9) environmental impact, and (10) the textile industry.

The study builds up the added value for the research practice and management theory through a comprehensive mapping of the sustainable supply chain management research field. Discovering research productivity trends and the most productive countries describes the development patterns of the research field. Identification of leading contributors indicates potential partners (universities and scholars) for further research collaboration. Finding the most attractive source titles shows publishing opportunities. Discovering leading thematic areas and emerging topics provides guidelines for scholars and identifies research gaps to be explored. The originality of the study derives from employing bibliometric methodology to support the research process and provide valuable, quantitative evidence for analysis and discussion.

Due to the conceptual character of the paper, it contributes first and foremost to the development of management theory. Nevertheless, some implications for business practice should be mentioned as well. As observed by Lis [39], in his bibliometric study of the learning organization concept, co-word analysis aimed at discovering and exploring leading and emerging topics in research fields enables managers to increase their awareness of the most important aspects related to the studied concepts and encourages them to identify potential gaps between theory and practice to be submitted for further research in academia. In our subjective opinion, this paper shows such a potential for bridging management theory and business practice related to sustainable supply chain management.

Understanding the context of the study requires unveiling limitations of the research process. Finding these weaknesses may be also a starting point for further research. Firstly, research profiling and science mapping are quantitative approaches, which analyze a wide body of publications and provide a large and comprehensive picture of the research field, but they may lack of a 'deep dive' into the thematic areas under the study. Moreover, we should consider the weaknesses of the methodology of co-word analysis (keywords co-occurrence analysis in the case of our study). They result from the fact that some publications do not include keywords, some types of publications may be underrepresented in bibliometric databases, and quality of co-word analysis depends on quality of indexing processes, which is out of control of the authors cf. [17,55,84]. Consequently, it is recommended to employ an eclectic and ambidextrous approach combining quantitative and qualitative methodologies and consider the findings of our analysis in conjunction with studies based on other methodological approaches such as qualitative literature reviews and meta-analysis studies. Secondly, in the sampling process we used the Scopus database only. Although Scopus is a well-recognized source of bibliometric data indexing high quality publications, it shows biases e.g., towards pieces of research work published in English [45,85]. As of 24 April 2020, English language items make 86\% of all documents indexed in Scopus. Therefore, replicating the study with the use of other bibliometric databases, especially those including more publications written in languages other than English, is recommended. Thirdly, while identifying leading and emerging topics with keywords co-occurrence analysis, the whole research field was the unit of analysis. This means that differences between subject areas have not been considered. Thus, subsequent studies focused on topical profiling of scientific output within leading subject areas (e.g., Business, Management and Accounting, Engineering or Environmental Science) seem to be an interesting line of research.

Providing recommendations for further research is an important outcome of any literature review or a bibliometric study. The field of research focused on sustainable supply chain management is very complex and progressive. In addition, supply chains are dynamic systems that evolve over time towards more sustainable practices. Hence, supply chain sustainability trajectories reflecting the holistic view on sustainable supply chain management, comprising economic, social as well as environmental dimensions appear as a promising future research direction. To gain broader views, 
the TBL approach encompassing economic, social and environmental aspects should be applied to evaluation of sustainable supply chain performance. In particular, the metrics associated with the economic, environmental and social performance of supply chains seem to be a highly interesting and important research area. Furthermore, the conducted study may inspire for in-depth research on the ways social issues are incorporated in supply chain management. Combining the observation that most studies on sustainability in supply chains focus mainly on environmental and economic dimensions with the fact that one of the emerging topics identified in our study refers to a human dimension of sustainable supply-chain management, we perceive a detailed study addressing social and human issues in the discussion on supply sustainability as necessary to enrich the understanding of sustainable supply-chain management. Taking into account that the aspects of the social/human dimension of SSCM are becoming more important in the modern world and are still more and more often exposed both by various organizations standing on human rights and responsible business, but also by numerous researchers, we assume that this will be an avenue for further research. As the pathways to advance human well-being ultimately require cooperation and dialogue between multiple actors within the supply chain as well as employ many levels of change, we perceive a detailed study addressing these issues as necessary to enrich the understanding of sustainable supply chain management. Furthermore, among the topics not widely discussed in the SSCM literature yet, we notice smart and digital performance management systems for SSCM as well as big data analytics impact on supply chain sustainability. Due to their novelty, these areas are just beginning to be explored by the researchers in the SSCM field, so they create a promising avenue for further research. Additionally, considering the last months' COVID-19 pandemic causing significant disruption to global supply chains, we perceive the issues referring to the COVID-19 outbreak impact on SSCM as an extremely interesting research area. At the moment businesses must respond on multiple fronts at once: at the same time that they work to protect their workers' safety, they must also safeguard their operational viability, now increasingly under strain from a historic supply-chain shock. It is already suspected that companies with superior supply chain management practices may better hold their value in market downswings. Taking the perspective of SSCM, the research focus on supply chain transparency-meaning that focal companies are aware of what is happening across their supply chains beyond the first tier —as well as smart SSCM systems seem very promising for further research.

Author Contributions: Conceptualization, A.L.; methodology, A.L.; data retrieval, A.L.; formal analysis, A.L., A.S., and M.T.; discussion, A.S.; writing-original draft preparation, A.L., A.S. and M.T.; writing-review and editing, A.L. and A.S.; visualization, A.L.; supervision, A.L.; project administration, A.L., A.S. and M.T.; funding acquisition, M.T. All authors have read and agreed to the published version of the manuscript.

Funding: This research was funded with statutory research budget by the Faculty of Economic Sciences and Management, Nicolaus Copernicus University in Torun, Poland.

Conflicts of Interest: The authors declare no conflicts of interest. The funders had no role in the design of the study; in the collection, analyses, or interpretation of data; in the writing of the manuscript, or in the decision to publish the results.

\section{References}

1. Oelze, N. Sustainable supply chain management implementation-Enablers and barriers in the textile industry. Sustainability 2017, 9, 1435. [CrossRef]

2. Carter, C.R.; Easton, P.L. Sustainable supply chain management: Evolution and future directions. Int. J. Phys. Distrib. Logist. Manag. 2011, 41, 46-62. [CrossRef]

3. Noorman, M.; Swierstra, T.; Zandbergen, D. Questioning the Normative Core of RI: The Challenges Posed to Stakeholder Engagement in a Corporate Setting. In Responsible Innovation 3: A European Agenda? Asveld, R., van Dam-Mieras, R., Swierstra, T., Lavrijssen, S., Linse, K., van den Hoven, J., Eds.; Springer International Publishing: Cham, Switzerland, 2017; pp. 231-249. ISBN 9783319648347.

4. Seuring, S.; Müller, M. From a literature review to a conceptual framework for sustainable supply chain management. J. Clean. Prod. 2008, 16, 1699-1710. [CrossRef] 
5. Seuring, S. A review of modeling approaches for sustainable supply chain management. Decis. Support. Syst. 2013, 54, 1513-1520. [CrossRef]

6. Handfield, R.B.; Nichols, E.L. Introduction to Supply Chain Management; Prentice-Hall: Upper Saddle River, NJ, USA, 1999; ISBN 9780136216162.

7. Pagell, M.; Wu, Z. Building a more complete theory of sustainable supply chain management using case studies of 10 exemplars. J. Supply Chain Manag. 2009, 45, 37-56. [CrossRef]

8. Sajjad, A.; Eweje, G.; Tappin, D. Sustainable supply chain management: Motivators and barriers. Bus. Strateg. Environ. 2015, 24, 643-655. [CrossRef]

9. Wu, Z.; Pagell, M. Balancing priorities: Decision-making in sustainable supply chain management. J. Oper. Manag. 2011, 29, 577-590. [CrossRef]

10. Büyüközkan, G.; Çifçi, G. A novel fuzzy multi-criteria decision framework for sustainable supplier selection with incomplete information. Comput. Ind. 2011, 62, 164-174. [CrossRef]

11. Reefke, H.; Ahmed, M.D.; Sundaram, D. Sustainable supply chain management-Decision making and support: The SSCM maturity model and system. Glob. Bus. Rev. 2014, 15, 1S-12S. [CrossRef]

12. Zimon, D.; Domingues, P. Proposal of a concept for improving the sustainable management of supply chains in the textile industry. Fibres Text. East. Eur. 2018, 26, 8-12. [CrossRef]

13. Tranfield, D.; Denyer, D.; Smart, P. Towards a methodology for developing evidence-informed management knowledge by means of systematic review. Br. J. Manag. 2003, 14, 207-222. [CrossRef]

14. Cook, D.J.; Mulrow, C.D.; Haynes, R.B. Systematic reviews: Synthesis of best evidence for clinical decisions. Ann. Intern. Med. 1997, 126, 376-380. [CrossRef]

15. Glass, G.V. Primary, secondary and meta-analysis of research. Educ. Res. 1976, 5, 3-8. [CrossRef]

16. Porter, A.L.; Kongthon, A.; Lu, J.C.C. Research profiling: Improving the literature review. Scientometrics 2002, 53, 351-370. [CrossRef]

17. Zupic, I.; Čater, T. Bibliometric methods in management and organization. Organ. Res. Methods 2015, 18, 429-472. [CrossRef]

18. Carter, C.R.; Rogers, D.S. A framework of sustainable supply chain management: Moving toward new theory. Int. J. Phys. Distrib. Logist. Manag. 2008, 38, 360-387. [CrossRef]

19. Carter, C.R.; Washispack, S. Mapping the path forward for sustainable supply chain management: A review of reviews. J. Bus. Logist. 2018, 39, 242-247. [CrossRef]

20. Panigrahi, S.S.; Bahinipati, B.; Jain, V. Sustainable supply chain management: A review of literature and implications for future research. Manag. Environ. Qual. An. Int. J. 2019, 30, 1001-1049. [CrossRef]

21. Patel, A.B.; Desai, T.N. A systematic review and meta-analysis of recent developments in sustainable supply chain management. Int. J. Logist. Res. Appl. 2019, 22, 349-370. [CrossRef]

22. Koberg, E.; Longoni, A. A systematic review of sustainable supply chain management in global supply chains. J. Clean. Prod. 2019, 207, 1084-1098. [CrossRef]

23. Callon, M.; Courtial, J.P.; Laville, F. Co-word analysis as a tool for describing the network of interactions between basic and technological research: The case of polymer chemistry. Scientometrics 1991, 22, 155-205. [CrossRef]

24. Wichaisri, S.; Sopadang, A. Trends and future directions in sustainable development. Sustain. Dev. 2018, 26, 1-17. [CrossRef]

25. De Jesus, A.; Antunes, P.; Ferreira dos Santos, R.; Mendonça, S. Eco-innovation in the transition to a circular economy: An analytical literature review. J. Clean. Prod. 2016, 172, 2999-3018. [CrossRef]

26. Bensalem, A.; Kin, V. A bibliometric analysis of reverse logistics from 1992 to 2017. Supply Chain Forum 2019, 20, 15-28. [CrossRef]

27. Lis, J.P.; Rodriguez, G.P.A.; Gaitan, M.; Viloria, A.; Vega-Riano, P. Current trends in international logistics research. J. Eng. Appl. Sci. 2017, 12, 2910-2914. [CrossRef]

28. Ye, Y. A bibliometric analysis of supply chain management research from the perspective of social network. Sci. Technol. Libr. 2019, 38, 224-242. [CrossRef]

29. Joshi, S.; Sharma, M.; Rathi, S. Forecasting in service supply chain systems: A state-of-the-art review using latent semantic analysis. Adv. Bus. Manag. Forecast. 2017, 12, 181-212. [CrossRef]

30. Gong, R.; Xue, J.; Zhao, L.; Zolotova, O.; Ji, X.; Xu, Y. A bibliometric analysis of green supply chain management based on the Web of Science (WOS) platform. Sustainability 2019, 11, 3459. [CrossRef] 
31. Shan, W.; Wang, J. Mapping the landscape and evolutions of green supply chain management. Sustainability 2018, 10, 597. [CrossRef]

32. Ahi, P.; Searcy, C. A comparative literature analysis of definitions for green and sustainable supply chain management. J. Clean. Prod. 2013, 52, 329-341. [CrossRef]

33. Boboc, D.; Constantin, F.; Diaconeasa, M.C. The use of sustainability concept regarding dairy and fruits in the Web of Science papers. Qual. Access Success 2019, 20, 82-89.

34. Ahi, P.; Searcy, C.; Jaber, M.Y. Energy-related performance measures employed in sustainable supply chains: A bibliometric analysis. Sustain. Prod. Consum. 2016, 7, 1-15. [CrossRef]

35. Ferreira Alves, P.A.; Schultz, G.; Dutra De Barcellos, M. Understanding sustainable supply chain coordination: A review of publications in Brazilian journals. J. Adm. Sci. 2018, 24, 1-17. [CrossRef]

36. Muñoz-Villamizar, A.; Solano, E.; Quintero-Araujo, C.; Santos, J. Sustainability and digitalization in supply chains: A bibliometric analysis. Uncertain Supply Chain Manag. 2019, 7, 703-712. [CrossRef]

37. Taticchi, P.; Garengo, P.; Nudurupati, S.S.; Tonelli, F.; Pasqualino, R. A review of decision-support tools and performance measurement and sustainable supply chain management. Int. J. Prod. Res. 2015, 53, 6473-6494. [CrossRef]

38. Lis, A. Managing Organization Development: Identifying Research Patterns and Mapping the Research Field. In Contemporary Challenges in Cooperation and Coopetition in the Age of Industry 4.0; Springer Proceedings in Business and Economics; Zakrzewska-Bielawska, A., Staniec, I., Eds.; Springer: Cham, Switzerland, 2020; pp. 375-396. ISBN 9783030305482.

39. Lis, A. Mapping Leading and Emerging Topics of Research on the Learning Organization Concept. In Organizations in the Face of Growing Competition in the Market; Ujwary-Gil, A., Potoczek, N., Eds.; Instytut Nauk Ekonomicznych Polskiej Akademii Nauk: Warsaw, Poland, 2019; pp. 57-84. ISBN 9788361597605.

40. Guo, D.; Chen, H.; Long, R.; Lu, H.; Long, Q. A co-word analysis of organizational constraints for maintaining sustainability. Sustainability 2017, 9, 1928. [CrossRef]

41. Schotten, M.; El Aisati, M.; Meester, W.J.N.; Steiginga, S.; Ross, C.A. A Brief History of Scopus: The World's Largest Abstract and Citation Database of Scientific Literature. In Research Analytics: Boosting University Productivity and Competitiveness through Scientometrics; Cantú-Ortiz, F.J., Ed.; Auerbach Publications: New York, NY, USA, 2017; pp. 31-58.

42. Thelwall, M. Dimensions: A competitor to Scopus and the Web of Science? J. Informetr. 2018, 12, 430-435. [CrossRef]

43. Falagas, M.E.; Pitsouni, E.I.; Malietzis, G.A.; Pappas, G. Comparison of PubMed, Scopus, Web of Science, and Google Scholar: Strengths and weaknesses. FASEB J. 2008, 22, 338-342. [CrossRef]

44. Zhu, J.; Liu, W. A tale of two databases: The use of Web of Science and Scopus in academic papers. Scientometrics 2020, 123, 321-335. [CrossRef]

45. Mongeon, P.; Paul-Hus, A. The journal coverage of Web of Science and Scopus: A comparative analysis. Scientometrics 2016, 106, 213-228. [CrossRef]

46. Harzing, A.W.; Alakangas, S. Google Scholar, Scopus and the Web of Science: A longitudinal and cross-disciplinary comparison. Scientometrics 2016, 106, 787-804. [CrossRef]

47. Aghaei Chadegani, A.; Salehi, H.; Md Yunus, M.M.; Farhadi, H.; Fooladi, M.; Farhadi, M.; Ale Ebrahim, N. A comparison between two main academic literature collections: Web of Science and Scopus Databases. Asian Soc. Sci. 2013, 9, 18-26. [CrossRef]

48. Scopus Content Coverage Guide 2020. Available online: https://www.elsevier.com/_data/assets/pdf_file/ 0007/69451/Scopus_ContentCoverage_Guide_WEB.pdf. (accessed on 26 April 2020).

49. Broadus, R.N. Toward a definition of "bibliometrics". Scientometrics 1987, 12, 373-379. [CrossRef]

50. Sudolska, A.; Lis, A.; Chodorek, M. Research profiling for responsible and sustainable innovations. Sustainability 2019, 11, 6553. [CrossRef]

51. Choi, D.G.; Lee, H.; Sung, T.K. Research profiling for "standardization and innovation". Scientometrics 2011, 88, 259-278. [CrossRef]

52. Martinez, H.; Jaime, A.; Camacho, J. Relative absorptive capacity: A research profiling. Scientometrics 2012, 92, 657-674. [CrossRef]

53. Sudolska, A.; Lis, A.; Błaś, R. Cloud computing research profiling: Mapping scholarly community and identifying thematic boundaries of the field. Soc. Sci. 2019, 8, 112. [CrossRef] 
54. Klincewicz, K.; Żemigała, M.; Mijal, M. Bibliometria w Zarządzaniu Technologiami i Badaniami Naukowymi; Ministerstwo Nauki i Szkolnictwa Wyższego: Warshaw, Poland, 2012.

55. He, Q. Knowledge discovery through co-word analysis. Libr. Trends 1999, 48, 133-159.

56. Lis, A. Keywords co-occurrence analysis of research on sustainable enterprise and sustainable organisation. J. Corp. Responsib. Leadersh. 2018, 5, 47-66. [CrossRef]

57. Van Eck, N.J.; Waltman, L. Software survey: VOSviewer, a computer program for bibliometric mapping. Scientometrics 2010, 84, 523-538. [CrossRef]

58. Van Eck, N.J.; Waltman, L. VOSviewer Manual; Universiteit Leiden: Leiden, The Netherlands, 2018.

59. Van Eck, N.J.; Waltman, L. Visualizing Bibliometric Networks. In Measuring Scholarly Impact: Methods and Practice; Ding, Y., Rousseau, R., Wolfram, D., Eds.; Springer International Publishing: Cham, Switzerland, 2014; pp. 285-320. ISBN 9783319103778.

60. Donohue, J.C. Understanding Scientific Literature: A Bibliometric Approach; MIT Press: Cambridge, MA, USA, 1974; ISBN 9780262040396.

61. Czakon, W. Metodyka systematycznego przegladu literatury. Przegląd Organ. 2011, 57-61. [CrossRef]

62. Zhang, J.; Yu, Q.; Zheng, F.; Long, C.; Lu, Z.; Duan, Z. Comparing keywords plus of WOS and author keywords: A case study of patient adherence research. J. Assoc. Inf. Sci. Technol. 2016, 67, 967-972. [CrossRef]

63. Brandenburg, M.; Govindan, K.; Sarkis, J.; Seuring, S. Quantitative models for sustainable supply chain management: Developments and directions. Eur. J. Oper. Res. 2014, 233, 299-312. [CrossRef]

64. Hassini, E.; Surti, C.; Searcy, C. A literature review and a case study of sustainable supply chains with a focus on metrics. Int. J. Prod. Econ. 2012, 140, 69-82. [CrossRef]

65. Govindan, K.; Khodaverdi, R.; Jafarian, A. A fuzzy multi criteria approach for measuring sustainability performance of a supplier based on triple bottom line approach. J. Clean. Prod. 2013, 47, 345-354. [CrossRef]

66. Gold, S.; Seuring, S.; Beske, P. Sustainable supply chain management and inter-organizational resources: A literature review. Corp. Soc. Responsib. Environ. Manag. 2010, 17, 230-245. [CrossRef]

67. Ashby, A.; Leat, M.; Hudson-Smith, M. Making connections: A review of supply chain management and sustainability literature. Supply Chain Manag. 2012, 17, 497-516. [CrossRef]

68. Tate, W.L.; Ellram, L.M.; Kirchoff, J.F. Corporate social responsibility reports: A thematic analysis related to supply chain management. J. Supply Chain Manag. 2010, 46, 19-44. [CrossRef]

69. Pagell, M.; Shevchenko, A. Why research in sustainable supply chain management should have no future. J. Supply Chain Manag. 2014, 50, 44-55. [CrossRef]

70. Beske, P.; Land, A.; Seuring, S. Sustainable supply chain management practices and dynamic capabilities in the food industry: A critical analysis of the literature. Int. J. Prod. Econ. 2014, 152, 131-143. [CrossRef]

71. Kannegiesser, M.; Günther, H.O. Sustainable development of global supply chains-Part 1: Sustainability optimization framework. Flex. Serv. Manuf. J. 2014, 26, 24-47. [CrossRef]

72. Elkington, J. Partnerships from cannibals with forks: The triple bottom line of 21st-century business. Environ. Qual. Manag. 1998, 8, 37-51. [CrossRef]

73. Köksal, D.; Strähle, J.; Müller, M.; Freise, M. Social sustainable supply chain management in the textile and apparel industry-A literature review. Sustainability 2017, 9, 100. [CrossRef]

74. Sancha, C.; Gimenez, C.; Sierra, V.; Kazeminia, A. Does implementing social supplier development practices pay off? Supply Chain Manag. 2015, 20, 389-403. [CrossRef]

75. Alhaddi, H. Triple bottom line and sustainability: A literature review. Bus. Manag. Stud. 2015, 1, 6-10. [CrossRef]

76. Zorzini, M.; Hendry, L.C.; Huq, F.A.; Stevenson, M. Socially responsible sourcing: Reviewing the literature and its use of theory. Int. J. Oper. Prod. Manag. 2015, 35, 60-109. [CrossRef]

77. Kannan, D.; Khodaverdi, R.; Olfat, L.; Jafarian, A.; Diabat, A. Integrated fuzzy multi criteria decision making method and multiobjective programming approach for supplier selection and order allocation in a green supply chain. J. Clean. Prod. 2013, 47, 355-367. [CrossRef]

78. González-Benito, J.; González-Benito, Ó. The role of stakeholder pressure and managerial values in the implementation of environmental logistics practices. Int. J. Prod. Res. 2006, 44, 1353-1373. [CrossRef]

79. Carter, C.R.; Kale, R.; Grimm, C.M. Environmental purchasing and firm performance: An empirical investigation. Transp. Res. Part. E Logist. Transp. Rev. 2000, 36, 219-228. [CrossRef]

80. Walker, H.; Jones, N. Sustainable supply chain management across the UK private sector. Supply Chain Manag. 2012, 17, 15-28. [CrossRef] 
81. Freise, M.; Seuring, S. Social and environmental risk management in supply chains: A survey in the clothing industry. Logist. Res. 2015, 8, 2. [CrossRef]

82. Giannakis, M.; Papadopoulos, T. Supply chain sustainability: A risk management approach. Int. J. Prod. Econ. 2016, 171, 455-470. [CrossRef]

83. Sudolska, A.; Drabkowska-Skarba, M.; Łapińska, J.; Kądzielawski, G.; Dziuba, K. Exploring corporate social responsibility practices in the clothing industry: The case of Polish and British companies. Fibres Text. East. Eur. 2020, 28, 14-19. [CrossRef]

84. Whittaker, J. Creativity and conformity in science: Titles, keywords and co-word analysis. Soc. Stud. Sci. 1989, 19, 473-496. [CrossRef]

85. Vera-Baceta, M.A.; Thelwall, M.; Kousha, K. Web of Science and Scopus language coverage. Scientometrics 2019, 121, 1803-1813. [CrossRef]

(C) 2020 by the authors. Licensee MDPI, Basel, Switzerland. This article is an open access article distributed under the terms and conditions of the Creative Commons Attribution (CC BY) license (http://creativecommons.org/licenses/by/4.0/). 